\title{
DROP DEAD OR A SLOW DEATH? AN ANALYSis OF RULe 4.33 OF THE ALBERTA RULES OF COURT
}

\author{
MElissa MORROW* AND R. MCKay White**
}

\begin{abstract}
From 2010 to 2013, the "Drop Dead Rule" in the Alberta Rules of Court underwent major amendments that resulted in new jurisprudence for resolution of all such applications. In this article, we conduct quantitative and qualitative analyses of the consequences of these amendments and the causes of these consequences. We find that the increase in applications, the longer time to resolution, and the inequitable impact on impecunious plaintiffs result in outcomes contrary to the objectives stated in the Foundational Rules. We provide evidence of the extent of these failures and recommendations on how to amend the Drop Dead Rule to result in fairer, more just, timelier, and more cost-effective resolutions.
\end{abstract}

\section{TABLE OF CONTENTS}

I. INTRODUCTION . . . . . . . . . . . . . . . . . . . . . . . . 957

II. History of THE Drop DeAd RUle IN Alberta $\ldots \ldots \ldots \ldots \ldots \ldots . \ldots 90$

III. Consequences of THE AMENDMEnTS $\ldots \ldots \ldots \ldots \ldots \ldots \ldots \ldots . \ldots 63$

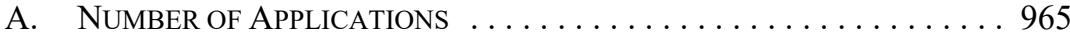

B. Time for ReSOlUtion $\ldots \ldots \ldots \ldots \ldots \ldots \ldots \ldots \ldots \ldots \ldots$

C. APPLICANT Success . . . . . . . . . . . . . . . . . . . . . 970

D. Propensity to ApPeAL $\ldots \ldots \ldots \ldots \ldots \ldots \ldots \ldots \ldots \ldots \ldots \ldots . \ldots \ldots$

IV. Why THE CONSEQUENCES? . . . . . . . . . . . . . . . . . 973

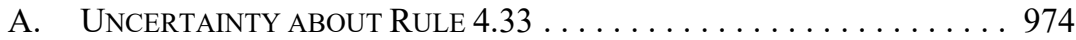

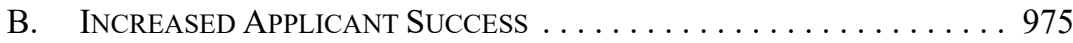

C. INCREASEd APPLICATIONS . . . . . . . . . . . . . . . . . . . . . . 979

V. IMPACT ON Foundational OBJECTIVES $\ldots \ldots \ldots \ldots \ldots \ldots \ldots \ldots . \ldots 91$

A. FAIRNESS AND Justice $\ldots \ldots \ldots \ldots \ldots \ldots 1$

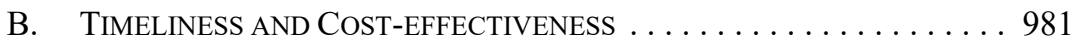

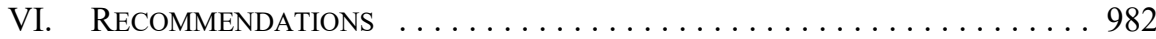

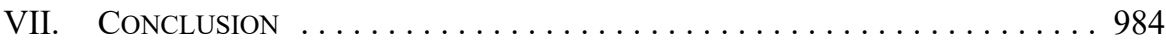

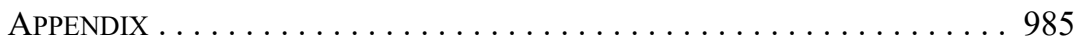

\section{INTRODUCTION}

In 2010, the Alberta Rules of Court ${ }^{1}$ underwent their first major overhaul into a new set of Rules (the "2010 Revision"). This revision included the addition of Rule 1.2, now known as the "Foundational Rules." The intent of the Foundational Rules, inter alia, is to facilitate the resolution of disputes, not only in a "timely and cost-effective way," but also "fairly and justly" (the "Foundational Objectives"). This article assesses whether Rule 4.33, the Rule

Melissa Morrow, BComm (Major: Legal Studies) has been engaged in many areas of law for more than 15 years and currently works in corporate governance. Her first hand experience has lead her to support equity, transparency, and consistency in the application of law.

** R. McKay White, BA, LLB, MA, PhD is an active (pro bono) member of the Alberta bar and associate professor at MacEwan University in Edmonton. AR 124/2010 [Rules 2010]. 
mandating the dismissal of stale litigation (the "Drop Dead Rule"), accomplishes the Foundational Objectives.

The Drop Dead Rule first came into force in 1994 as Rule 244.1. ${ }^{2}$ The 2010 Revision replaced it with Rule 15.4, a temporary Drop Dead Rule transitioning to the shorter time window in Rule 4.33. ${ }^{3}$ Rule 4.33 was amended in 2013 (the "2013 Amendment") and subsequently came into force 1 November $2013 .{ }^{4}$ In proposing the new rules, the Alberta Law Reform Institute (ALRI) explained, "[t]he acid test will be whether the proposed rules meet the fundamental purpose set out in proposed r. 1.2(1)." "To this end, it suggested, "[o]nce adopted, [the proposed rules] should be monitored and adjusted as necessary." In this spirit, we quantify and assess the consequences of the 2013 Amendments and subsequent interpretation of the Drop Dead Rule in the context of the Foundational Rules. We determine whether the current application of the Drop Dead Rule abides by the Foundational Objectives or contradicts them. To assess this issue, we consider the following questions:

1. What has happened in Drop Dead Applications since the 2013 Amendment?

2. Why did this happen?

3. Does it conform to the Foundational Objectives?

The combination of the 2013 Amendment and the addition of the Foundational Rules has resulted in new jurisprudence for Drop Dead Applications. ${ }^{7}$ In the consequent surge in such Applications, ${ }^{8}$ we find there have been four principal consequences (collectively the "Consequences"):

1. there are significantly more Drop Dead Applications;

2. Drop Dead Applications are taking significantly longer to achieve final resolution;

3. significantly more Drop Dead Applications result in the dismissal of a claim; and

4. significantly more Drop Dead Applications are appealed.

We argue the Consequences are contradictory to the Foundational Objectives. The elevated bar set by the courts, hazy to all but those with the keenest foresight, has created uncertainty and apprehension for plaintiffs and their legal counsel. The Drop Dead Rule can deter the behaviour it is designed to prohibit — delay in resolution — only if its application is predictable. ${ }^{9}$ Where once it was relatively uncomplicated to discern whether a plaintiff had materially advanced its claim within the allotted time, now such analysis is surrounded by doubt. This creates lengthy, and more numerous, applications and appeals, with consequent increased strain on judicial resources. Plaintiffs, their counsel, and taxpayers are facing

Alberta Rules of Court, AR 390/68 [Rules 1968].

Supra note $1, \mathrm{r} 15.4$.

Alta Reg 140/2013.

Alberta Law Reform Institute, "Rules of Court Project: Final Report No. 95” (Edmonton: ALRI, 2008) at para 14

Ibid at para 47.

We can likely add Hryniakv Mauldin, 2014 SCC 7 [Hryniak] as another cause of the new jurisprudence, as the change in approach to Drop Dead Applications did not occur until after this decision. This is discussed in more detail below.

8 Law Society of Alberta,"Dismissal for Long Delay and Prejudice," online: $<$ lawsociety.ab.ca/resourcecentre/key-resources/insurance-resources-aliadvisories/dismissal-for-long-delay-and-prejudice/ $>$.

This point is persuasively argued in Barbara Billingsley, "Hryniak v. Mauldin Comes to Alberta: Summary Judgment, Culture Shift, and the Future of Civil Trials" (2017) 55:1 Alta L Rev 1 at 19-20. 
serious repercussions as a result, with inequitable consequences for impecunious complainants. More court and party resources and time are consumed, and inordinate responsibility is placed on plaintiffs, while defendants are given new tactics to avoid liability with little adverse consequences. As a result, the immediacy of the former Drop Dead Rule has been foregone for higher costs to all parties involved and the slow death of otherwise legitimate actions. This is neither fair and just, nor timely and cost-effective.

Many of the published materials regarding the changes to the Drop Dead Rule came shortly after the 2010 Revision, but prior to the 2013 Amendment and present form of the Rule. Authors predicted the impact and outcomes the 2010 Revision would have. Marco Poretti optimistically reported, "[i]t is expected that the new Rules of Court will encourage parties - and legal counsel - to resolve claims as effectively and efficiently as possible, at the least possible expense. ${ }^{\prime 10}$ In 2012, both the Legal Education Society of Alberta and the Law Society of Alberta published materials that detailed what the changes were and how the changes were expected to affect the application of the Drop Dead Rule. ${ }^{11}$ The latter was more cautious, pointing out some lawyers' concerns that the shorter time window would make practice more onerous and could even slow litigation. ${ }^{12}$ All these articles addressed the 2010 Revision, not the 2013 Amendment. Though none of these authors have published a followup article assessing whether their predictions were realized, the Alberta Lawyers Insurance Association (ALIA) has reported a considerable increase in Drop Dead Applications since the 2013 Amendment. $^{13}$

A 2018 article by Cole Lefebvre and John MacKay describes the Foundational Rules and summarizes court approaches to Rule 4.33. ${ }^{14}$ Although it highlights a general sense of uncertainty in Drop Dead Applications, the article does not provide concrete research or data to support that sense of uncertainty, nor does it consider the consequences for litigants and society. There simply is no quantitative or qualitative research published assessing the consequences of the new Drop Dead Rule jurisprudence in relation to the Foundational Rules. The ALRI's "acid test" has, to date, not occurred.

This article provides the necessary acid test, fills the gap in research, and provides a better understanding about the Drop Dead Rule's ability to achieve the Foundational Objectives and how decisions are impacting plaintiffs and their legal counsel. By quantifying what has happened since the 2013 Amendment, we highlight the consequences of the new approach to Drop Dead Applications and provide guidance to the legal community where research is currently lacking.

First, this article examines the history of the Drop Dead Rule, the changes to the Rule itself, and the addition of the Foundational Rules to the Rules. It then quantitatively analyzes

Marco Poretti, "The New Alberta Rules of Court - It's Time to Bring Down the Cost of Litigation" (2011) 22:1 Edmontonians 23.

Legal Education Society of Alberta, Case Management, Litigation Plans, and the "Drop Dead" Rule (Alberta: LESA, 2012); Nancy Carruthers, "Ethically Speaking: Procedural and Ethical Obligations Under the New 'Drop Dead' Rule,” The Advisory (2012) 10:1.

Carruthers, ibid at $1-2$.

The Law Society of Alberta, supra note 8.

Cole Lebebvre \& John MacKay, "The 'Drop-Dead' Rule in Civil Litigation,” LawNow (4 May 2018), online: <lawnow.org/the-drop-dead-rule-in-civil-litigation/>. 
the outcomes of Drop Dead Applications to determine the Consequences of the Foundational Rules and the 2013 Amendment. The following section qualitatively analyzes decisions and circumstances to determine why the Consequences have occurred. This includes an analysis of many of the Court of Queen's Bench rulings since the 2010 Revision, and all Rule 4.33 decisions reported in the first quarter of 2019, including Alberta Court of Appeal rulings. The article then assesses what these results mean for the Foundational Objectives, followed by recommendations for improving performance.

\section{History of The Drop Dead Rule in Alberta}

Figure 1 illustrates the steps in the evolution of the Drop Dead Rule. Until 1994, delay was regulated by Rule 243, which required plaintiffs to apply to the court for leave to continue the action if it had been more than one year since last taking a "step." ${ }^{\text {15 }}$ Rule 244.1 came into force 1 October 1994, stating:

244.1(1) Subject to Rule 244.2, where 5 or more years have expired from the time that the last thing was done in an action that materially advances the action, the Court shall, on the motion of a party to the action, dismiss that portion or part of the action that relates to the party bringing the motion. ${ }^{16}$

This eliminated discretion, mandating dismissal if there had been five years without a "thing" to "materially" advance the action. Judicial decisions concentrated on the meaning of "thing" and "material." The Court of Appeal noted that, when there is a change in wording, such as from "step" to "thing," one must presume a different meaning. ${ }^{17}$ It concluded using the word "thing" broadened the scope of what the Rule encompassed. ${ }^{18}$ The Court of Appeal decision in Alberta v. Morasch set the process to determine such "things" (the "Morasch Analysis"). ${ }^{19}$ A court was to assess each "thing" done in the five years prior to the application for whether it materially advanced the action toward trial. If a "thing" was a procedural step required by the Rules, it was automatically considered to have advanced the action. Any other "thing" was to be "examined in light of the purpose of R. 244.1."20 This latter part of the Morasch Analysis was later described as a "functional analysis" in which the court determined whether that "thing" on its own "genuinely further[ed] the litigation in a meaningful way." ${ }^{21}$ Following these landmark cases, ${ }^{22}$ commentary and judicial decisions created lists of what "things" would "materially advance" a claim. ${ }^{23}$

Rules 1968, supra note 2, r 243.

Ibid.

It is noteworthy that no such presumption was made when the wording changed from "material" to "significant."

Bishop v Calgary (City), 1998 ABCA 23 at para 10 [Bishop].

2000 ABCA 24 [Morasch].

Ibid at para 9 .

Phillips $v$ Sowan, 2007 ABCA 101 at para 5 [Phillips].

Ro-Dar Contracting Ltd v Verbeek Sand \& Gravel Inc, 2016 ABCA 123 [Ro-Dar Contracting]. The 2000 decision of the Alberta Court of Appeal in Morasch, supra note 19, is one of the most cited cases for defining what "thing" would "materially advance" a claim.

23 See also Calgary (City of) v Chisan, 2000 ABCA 313 [Chisan] and Jensen Shawa Solomon Duguid Hawkes LLP, "Rules" (April 2011), online: <jssbarristers.ca/files/pdf/JSS-Barristers-RULES-Vol1Issue1.pdf $>$ for other examples of commentary and decisions that previously described what "thing" "materially advanced" an action. 
Figure 1: EVolution OF THE DROP DEAd RUle in Alberta

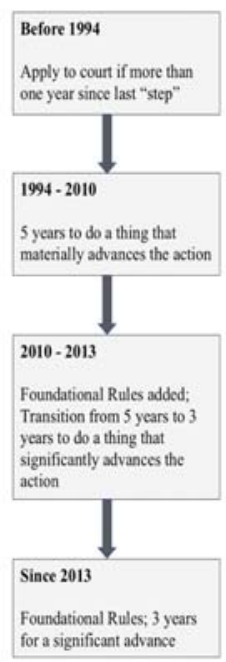

In 2010, after extensive consultation with the ALRI, more than 40 open meetings with legal groups, and two public forums, the revised Rules were introduced. ${ }^{24}$ The 2010 Revision made three explicit changes to the Drop Dead Rule: the introduction of Rule 1.2, a shortened time window for advancing an action, and wording changes to the Drop Dead Rule itself.

The Foundational Rules were not previously included in any form in any other version of the Rules. Its inclusion in the 2010 Revision was meant to act as an encompassing authority to the entire set of Rules. When applying the Rules, the courts are to put their minds to the following:

1.2(1) The purpose of these rules is to provide a means by which claims can be fairly and justly resolved in or by a court process in a timely and cost-effective way.

(2) In particular, these rules are intended to be used

(a) to identify the real issues in dispute,

(b) to facilitate the quickest means of resolving a claim at the least expense,

(c) to encourage the parties to resolve the claims themselves, by agreement, with or without assistance, as early in the process as practicable,

(d) to oblige the parties to communicate honestly, openly and in a timely way, and

(e) to provide an effective, efficient and credible system of remedies and sanctions to enforce these rules and orders and judgments. ${ }^{25}$ 
The Drop Dead Rule became Rule 4.33, stating: "If 2 or more years has passed after the last thing done that significantly advanced an action, the Court, on application, must dismiss the action against the applicant." ${ }^{26}$ A number of exceptions were provided. ${ }^{27}$ Rule $15.4(1)$ applied during a two-year transitional period before Rule 4.33 came into force. It phrased the Drop Dead Rule as "(a) after the coming into force of this rule, 2 years has elapsed since the last thing done to significantly advance the action, or (b) 5 years has elapsed since the last thing done to significantly advance the action, whichever comes first." 28 Just before the twoyear transitional period expired, these transitional rules were amended such that Rule 15.4(1)(a) read "3 years" instead of " 2 years," and the transitional period was extended to be three years. From 1 November 2010 to 1 November 2013 (the "Transition Period"), the two key amendments to the Drop Dead Rule were the change in wording from "material" to "significantly," and the anticipated reduction in time from five years to three.

During the Transition Period, the addition of the Foundational Rules and the change in wording from "material" to "significantly" had no impact on Drop Dead Applications. Despite the earlier presumption that a change in wording indicates a change in meaning, ${ }^{29}$ courts concluded, "there is no material or significant difference between 'material' and "significant.", 30 They similarly concluded, "there is no significant or material difference between the two rules which would affect the determination" of a Drop Dead Application. ${ }^{31}$ All reported decisions continued to apply the old jurisprudence and to adjudicate Drop Dead Applications using the Morasch Analysis. ${ }^{32}$

Before the end of the transition period, Rule 4.33 was amended again to its present wording. The current criterion for mandatory dismissal is: "If 3 or more years have passed without a significant advance in an action, the Court, on application, must dismiss the action as against the applicant," subject to stated exceptions. ${ }^{33}$ Thus, the key changes to the Drop Dead Rule from its inception to its current form are:

1. the addition of the Foundational Rules;

2. deletion of reference to "thing";

3. requiring a "significant" advance rather than a "material" advance; and

4. shortening the time frame from five years to three years.

Ibid, r 4.33(1) as it appeared on 1 November 2010.

Ibid.

Ibid.

Bishop, supra note 18 at para 10.

Ro-Dar Contracting, supra note 22 at para 16.

Bahcheli $v$ Yorkton Securities Inc, 2010 ABQB 824 at para 27 [Bahcheli].

See e.g. Brar v Pawa, 2010 ABQB 779; Bahcheli, ibid; Donnellyv Brick Warehouse Corporation, 2013 ABQB 621.

33 Rules 2010, supra note 1, r 4.33(2) (the exceptions are: (i) the action was stayed or adjourned by an order, (ii) an order set out a suspension period not to be included in computing time under the Drop Dead Rule, (iii) the delay was provided for in a litigation plan, or (iv) the applicant has participated in proceedings since the delay). 
The issue now is: what are the consequences of these changes and subsequent court decisions on Drop Dead Applications and the parties to litigation?

\section{Consequences of THE Amendments}

As the 2010 Revision had no perceptible impact on the application of the Drop Dead Rule, ${ }^{34}$ we quantitatively analyzed what happened after the 2013 Amendment. To do so, we collected every reported decision of a Drop Dead Application in Alberta since the Rule's inception in 1994 until the time of writing. ${ }^{35}$ For each application, we noted:

a) the date the application was first filed, if reported;

b) the date the application was heard at each level of court (Master, Queen's Bench Justice, or Court of Appeal), if applicable and if reported;

c) the date the final decision was given; and

d) for each applicable level of court, whether the application was granted or denied.

We analyzed this information to assess:

a) the number of applications over time, their frequency, and trends over time;

b) the length of time from the filing of an application to final resolution (that is, the date parties received the final decision) and trends over time;

c) trends in proportions of successful applications versus unsuccessful applications;

d) trends in successful and unsuccessful appeals; and

e) the propensity of parties to appeal.

We acquired 246 distinct applications with reported decisions. The date the initiating application was filed was given by 174 of them ( 71 percent). Table 1 provides the summary statistics of this dataset. From our analysis of this data, we found the 2013 Amendment and subsequent jurisprudence have had four major Consequences:

1. there are significantly more Drop Dead Applications;

2. Drop Dead Applications are taking significantly longer to achieve final resolution;

3. significantly more Drop Dead Applications result in the dismissal of a claim; and

4. $\quad$ significantly more Drop Dead Applications are appealed.

34 Table 8 in Appendix I, below, summarizes key cases during the Transition Period.

35 These reported decisions were found using Westlaw by identifying every case that cited Rule 244.1, Rule 15.4, or Rule 4.33. There are limitations to this data. Not all applications have a reported decision; this was evident from the appeal decisions we found for which there was no reported decision from the lower courts. Also, we could not find the date for each stage of each application. Our primary concern with this limitation was not having the date the application was filed. Later in this article we explain the steps we took to minimize any bias this causes in the results. 
Table 1: Statistics of Reported Drop Dead Applications

\begin{tabular}{|c|c|c|c|c|}
\hline Variable & Full Sample & $\begin{array}{l}\text { Before } 2013 \\
\text { Amendment }\end{array}$ & $\begin{array}{l}\text { After } 2013 \\
\text { Amendment }\end{array}$ & $\begin{array}{c}\text { Statistical } \\
\text { Significance }^{36}\end{array}$ \\
\hline $\begin{array}{l}\text { Number of Reported } \\
\text { Applications }\end{array}$ & 246 & 145 & 101 & N/A \\
\hline $\begin{array}{l}\text { Number that Began } \\
\text { with Master }^{37}\end{array}$ & $\begin{array}{c}168 \\
68.3 \% \text { of Total } \\
\text { Applications }\end{array}$ & $\begin{array}{c}98 \\
67.6 \% \text { of Total } \\
\text { Applications }\end{array}$ & $\begin{array}{c}70 \\
69.3 \% \text { of Total } \\
\text { Applications }\end{array}$ & $\begin{array}{c}\text { Not Significant } \\
(0.782)\end{array}$ \\
\hline $\begin{array}{l}\text { Number that Began } \\
\text { with Justice }\end{array}$ & $\begin{array}{c}78 \\
31.7 \% \text { of Total } \\
\text { Applications }\end{array}$ & $\begin{array}{c}47 \\
32.4 \% \text { of Total } \\
\text { Applications }\end{array}$ & $\begin{array}{c}31 \\
30.7 \% \text { of Total } \\
\text { Applications }\end{array}$ & $\begin{array}{l}\text { Not significant } \\
\quad(0.782)\end{array}$ \\
\hline $\begin{array}{l}\text { Number that Went to } \\
\text { Court of Appeal }\end{array}$ & $\begin{array}{c}49 \\
19.9 \% \text { of Total } \\
\text { Applications }\end{array}$ & $\begin{array}{c}30 \\
20.1 \% \text { of Total } \\
\text { Applications }\end{array}$ & $\begin{array}{c}19 \\
18.8 \% \text { of Total } \\
\text { Applications }\end{array}$ & $\begin{array}{c}\text { Not significant } \\
\quad(0.310)\end{array}$ \\
\hline $\begin{array}{l}\text { Number Appealed at } \\
\text { Least Once }\end{array}$ & $\begin{array}{c}99 \\
40.2 \% \text { of Total } \\
\text { Applications }\end{array}$ & $\begin{array}{c}58 \\
40.0 \% \text { of Total } \\
\text { Applications }\end{array}$ & $\begin{array}{c}41 \\
40.6 \% \text { of Total } \\
\text { Applications }\end{array}$ & $\begin{array}{c}\text { Not significant } \\
\quad(0.779)\end{array}$ \\
\hline $\begin{array}{l}\text { Number Overturned } \\
\text { at Least Once }\end{array}$ & $\begin{array}{c}38 \\
38.4 \% \text { of } \\
\text { Appealed }\end{array}$ & $\begin{array}{c}26 \\
44.8 \% \text { of Appealed }\end{array}$ & $\begin{array}{c}12 \\
29.3 \% \text { of Appealed }\end{array}$ & $\begin{array}{c}\text { Significant at } 1 \% \text { level } \\
(0.009)\end{array}$ \\
\hline $\begin{array}{l}\text { Number Granted in } \\
\text { Original Hearing }\end{array}$ & $\begin{array}{c}136 \\
55.3 \% \text { of Total } \\
\text { Applications }\end{array}$ & $\begin{array}{c}87 \\
60.0 \% \text { of Total } \\
\text { Applications }\end{array}$ & $\begin{array}{c}49 \\
48.5 \% \text { of Total } \\
\text { Applications }\end{array}$ & $\begin{array}{c}\text { Significant at } 10 \% \\
\text { level } \\
(0.079)\end{array}$ \\
\hline $\begin{array}{l}\text { Number Denied in } \\
\text { Original Hearing }\end{array}$ & $\begin{array}{c}110 \\
44.7 \% \text { of Total } \\
\text { Applications }\end{array}$ & $\begin{array}{c}58 \\
40.0 \% \text { of Total } \\
\text { Applications }\end{array}$ & $\begin{array}{c}52 \\
51.5 \% \text { of Total } \\
\text { Applications }\end{array}$ & $\begin{array}{c}\text { Significant at } 10 \% \\
\text { level } \\
(0.079)\end{array}$ \\
\hline $\begin{array}{l}\text { Number Granted in } \\
\text { Final Decision }\end{array}$ & $\begin{array}{c}129 \\
52.4 \% \text { of Total } \\
\text { Applications }\end{array}$ & $\begin{array}{c}75 \\
51.7 \% \text { of Total } \\
\text { Applications }\end{array}$ & $\begin{array}{c}54 \\
53.5 \% \text { of Total } \\
\text { Applications }\end{array}$ & $\begin{array}{c}\text { Not significant } \\
(0.789)\end{array}$ \\
\hline $\begin{array}{l}\text { Number Denied in } \\
\text { Final Decision }\end{array}$ & $\begin{array}{c}117 \\
47.6 \% \text { of Total } \\
\text { Applications }\end{array}$ & $\begin{array}{c}70 \\
48.3 \% \text { of Total } \\
\text { Applications }\end{array}$ & $\begin{array}{c}47 \\
46.5 \% \text { of Total } \\
\text { Applications }\end{array}$ & $\begin{array}{c}\text { Not significant } \\
(0.789)\end{array}$ \\
\hline $\begin{array}{l}\text { Average Length } \\
\text { from Filing to Final } \\
\text { Decision }\end{array}$ & 12.84 Months & 10.66 Months & 15.66 Months & $\begin{array}{c}\text { Significant at } 1 \% \text { level } \\
(0.000)\end{array}$ \\
\hline
\end{tabular}

This reports the results of testing whether the averages of the variables are statistically different pre-2013 and post-2013 using a t-test. The value in brackets is the p-value of the t-statistic.

Based on reported decisions only. This is a weakness of the analysis. We cannot know whether, were it possible to include unreported decisions, their inclusion would affect the results. Given that these circumstances existed both before the 2013 Amendment and after, it is a problem only if reporting patterns changed. 


\section{A. Number of Applications}

There were 145 reported applications under Rules 244.1 and 15.4, with an average of 5.4 reported applications in a given year. Within the first five-and-a-half years of Rule 4.33, there have been 101 reported applications, with an average of 14.4 reported applications in a given year. This is a significantly higher average of reported applications. ${ }^{38} \mathrm{We}$ wanted to determine whether this jump in the number of applications correlates with the new formulation of the Drop Dead Rule, or whether there was a general increasing trend in such applications. We therefore examined the number of applications initiated in each year. ${ }^{39}$ Table 2 reports the numbers and Figure 2 illustrates.

\section{TABLE 2: NuMber OF APPLiCATIONS EACH Year}

\begin{tabular}{|c|c|c|c|}
\hline Year & $\begin{array}{l}\text { Number of } \\
\text { Applications Filed }\end{array}$ & Year & $\begin{array}{l}\text { Number of } \\
\text { Applications Filed }\end{array}$ \\
\hline 1995 & 1 & 2007 & 7 \\
\hline 1996 & 2 & 2008 & 9 \\
\hline 1997 & 4 & 2009 & 1 \\
\hline 1998 & 2 & 2010 & 7 \\
\hline 1999 & 6 & 2011 & 5 \\
\hline 2000 & 3 & 2012 & 2 \\
\hline 2001 & 8 & 2013 & 7 \\
\hline 2002 & 8 & 2014 & 28 \\
\hline 2003 & 3 & 2015 & 7 \\
\hline 2004 & 2 & 2016 & 12 \\
\hline 2005 & 13 & 2017 & 17 \\
\hline 2006 & 12 & 2018 & 8 \\
\hline
\end{tabular}

T-test for whether difference in averages is significant resulted in a $\mathrm{p}$-value $=0.012$, making the two averages significantly different at a 5 percent level of significance.

Rules 2010, supra note 1, r 4.33; Rules 1968, supra note 2, r 244.1. Rule 244.1 came into effect 1 October 1994, and Rule 4.33 came into force 1 November 2013. Throughout our analysis, we therefore use 1 November through 31 October as a year, such that a year designated as "1995," for example, means the period 1 November 1994 through 31 October 1995. 
Figure 2: Number of Applications Begun Each Year*

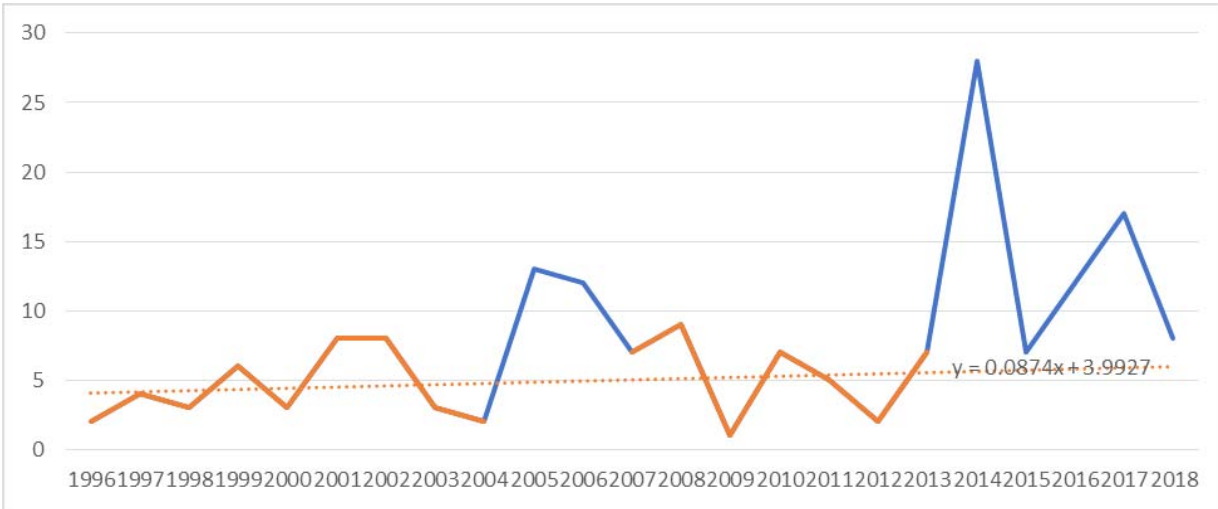

*Note: The solid orange lines indicate periods we consider "normal activity." The solid blue lines indicate periods of unusually high numbers of applications. The dotted orange line illustrates the estimated trend in applications based only on periods of normal activity.

There have been two periods of high activity: 2005-2006 and 2014-2018. The second spike (beginning 1 November 2013) corresponds with the inauguration of Rule 4.33. Ten reported applications were made in the first month alone. We used the dummy variable method to test whether the number of reported applications each year in the two periods of high activity had significantly different trends than in other years. ${ }^{40}$ These two periods were each found to have statistically more reported applications each year.

We wanted a baseline trend for reported applications each year against which to compare periods of unusual activity. We therefore estimated a linear trend in the number of applications each year excluding 2005-2006 and 2014-2018. This resulted in Equation (1). ${ }^{41}$

$$
y=0.0874 x+3.9927
$$

where,

$y$ is the estimated number of applications

$x$ is the year $(1996=1,1997=2$, etc. $)$

This required OLS regression of four variables: the number of reported applications, the year, a dummy variable to indicate whether the year was within the 2005-2006 period, and a second dummy variable to indicate whether the year was within the 2014-2018 period. We regressed the number of reported applications on the other three variables and tested the significance of the coefficients on the dummy variables. The p-value for the coefficient for the first dummy variable was 0.029 ; it was 0.049 for the second dummy variable. As both coefficients are significant at the 5 percent level of significance, we concluded these two periods of higher activity were significantly different than other years.

41 The constant is statistically significant $(p$-value $=0.009)$ but the slope coefficient is not ( $p$-value $=$ 0.482 ). This means we could propose a flat baseline of 4 applications in any given year. We retain the slope, even though statistically not significant, because allowing for an increase in the baseline number of applications each year challenges our proposition that Rule 4.33 has increased those applications. 
The trend in the number of reported applications is only slightly increasing $(0.0874$ more applications in each year). Based on that trend, the estimated number of reported applications grew from four in 1996 (versus two actual reported applications) to 5.7 in 2014 (versus 28 actual reported applications) and to an estimated six reported applications in 2018 (versus eight actual reported applications).

We use the estimated trend line as the estimate of normal activity. This means that since the 2013 Amendment, there has been a significant increase in the number of reported applications. In the first year of enactment, there were 28 reported applications instead of the expected normal of 5.7. The fewer reported applications in 2018 may indicate activity is returning to normal. It is likely, however, that we do not yet have complete data for 2018 . On average for reported decisions, applications filed in 2017 took 15.5 months to conclude. Therefore, at the time of writing, we are likely still waiting for reported decisions for 2018 applications.

This increase in the number of reported applications could mean the number of actual applications increased, that more applications were reported, or a combination of both. One may propose the sharp increase in reported applications is simply that Justices and Masters provided more written decisions in order to give counsel guidance in response to the amendment to the Drop Dead Rule. Not only is there no evidence to support this proposal, but those written decisions suggest otherwise. For over six months, written decisions consistently retained the same approach as under Rule 15.4 - the test did not change and all the old jurisprudence continued to apply. ${ }^{42}$ This is antithetical to a desire to provide clarification.

There is evidence the surge in reported applications reflects a surge in actual applications. In his decision in Krieter v. Alberta, Master Hanebury noted, "On November 1, 2013, the time line under the Alberta Rules of Court for bringing a drop dead application was shortened from 5 years to 3 years and Shell filed this application the very same day. Similar applications were filed by other defendants." 43 Two other applications filed on 1 November 2013 are reported. ${ }^{44}$ All three of these applications were feasible only because the 2013 Amendment reduced the time for advance from five years to three years, indicating that at least some of the applications brought at that time were the direct result of the amendment.

Of the ten reported decisions that originated in November 2013, none would have been feasible but for the reduction in the timeline. This is, again, indicative that the increase in reported applications reflects an increase in applications. Furthermore, the original decisionmaker in four of these applications (one Justice, three Masters) did not provide a written decision. This is counter to the proposal that the number of reported decisions was an effect of Justices and Masters desiring to provide guidance in applying the new rule. We therefore conclude the sharp increase in reported applications coinciding with the 2013 Amendment coming into force is more likely explained by an increase in applications rather than an increase in reporting decisions. 


\section{B. TIME FOR RESOLUTION}

All reported decisions provided the date the final decision was given. But we needed the date the application was filed in order to determine the length of time from filing an application to achieving final resolution. Not every reported case gives this information. We therefore had to work with a subset of our sample. As the ability to generalize our results depends on whether our subset is suitably representative of the full sample, we compared key statistics between the full sample and the subset. This comparison is given in Table 3 .

The number appealed at least once is the only significant difference. The point that appeals give rise to another decision in which the application date may be given likely explains why the subset exhibits more appeals. Since appeals extend the length of time to final resolution, it is likely that our analysis overstates how long it takes for Drop Dead Applications to be resolved. Further, and as explained below, appeals increased after the 2013 Amendment. It is therefore likely that the bias is worse for applications made since that time. This must be kept in mind when interpreting results.

Table 4 provides the average number of months taken to resolve applications. Prior to the 2013 Amendment, the average length of time for resolution was 10.66 months. Under Rule 4.33, the average has been 15.74 months. The question is whether this change can be attributed to the 2013 Amendment and subsequent judicial application of that amendment.

Until 2007, the average length of time for resolution was 7.64 months. There was a temporary spike of an average of 16.16 months from 2007 through 2011 . The average then returned to 7.5 months for the two years before the 2013 Amendment. For the years 2014 through 2017, the average was 18.0 months. ${ }^{45}$ As reported in Table 1, this increased time to resolution is statistically significant. ${ }^{46}$ Unless the bias we have identified is large, there has been an increase in the time taken to resolve Drop Dead Applications since the 2013 Amendment. ${ }^{47}$ reported. trials). If such a factor can be identified and correlated with both the previous period and the period beginning in 2013, it will reduce the weight placed on the 2013 Amendment for the increased time for resolution of Drop Dead Applications. 
Table 3: Comparison of Full Sample to Subset with Application Dates

\begin{tabular}{|c|c|c|c|}
\hline Variable & $\begin{array}{l}\text { Application } \\
\text { Sample }\end{array}$ & Full Sample & Comments $^{48}$ \\
\hline $\begin{array}{l}\text { Number of Reported } \\
\text { Applications }\end{array}$ & 174 & 246 & $71 \%$ of full sample \\
\hline Number that Began Master & $\begin{array}{l}121 \\
69.5 \% \text { of Total }\end{array}$ & $\begin{array}{l}168 \\
68.3 \% \text { of Total }\end{array}$ & $\begin{array}{l}1.2 \% \text { difference } \\
\text { Not significant }(0.621)\end{array}$ \\
\hline Number that Began Judge & $\begin{array}{l}53 \\
30.5 \% \text { of Total }\end{array}$ & $\begin{array}{l}78 \\
31.7 \% \text { of Total }\end{array}$ & $\begin{array}{l}1.2 \% \text { difference } \\
\text { Not significant } \\
(0.621) \\
\end{array}$ \\
\hline Number Appealed at Least Once & $\begin{array}{l}82 \\
47.1 \% \text { of Total }\end{array}$ & $\begin{array}{l}99 \\
40.2 \% \text { of Total }\end{array}$ & $\begin{array}{l}6.9 \% \text { difference } \\
\text { Significant at } 1 \% \text { level } \\
(0.000)\end{array}$ \\
\hline Number Overturned Once & $\begin{array}{l}27 \\
32.9 \% \text { of Appealed }\end{array}$ & $\begin{array}{l}33 \\
33.3 \% \text { of Appealed }\end{array}$ & $\begin{array}{l}0.4 \% \text { difference } \\
\text { Not significant }(0.732)\end{array}$ \\
\hline Number Overturned Twice & $\begin{array}{l}5 \\
21.7 \% \text { of Appealed } \\
\text { Twice }\end{array}$ & $\begin{array}{l}5 \\
19.2 \% \text { of Appealed } \\
\text { Twice }\end{array}$ & $\begin{array}{l}2.5 \% \text { difference } \\
\text { Not significant }(0.247)\end{array}$ \\
\hline $\begin{array}{l}\text { Number Granted in Original } \\
\text { Application }\end{array}$ & $\begin{array}{l}94 \\
54.0 \% \text { of Total }\end{array}$ & $\begin{array}{l}136 \\
55.3 \% \text { of Total }\end{array}$ & $\begin{array}{l}1.3 \% \text { difference } \\
\text { Not significant }(0.691)\end{array}$ \\
\hline $\begin{array}{l}\text { Number Denied in Original } \\
\text { Application }\end{array}$ & $\begin{array}{l}80 \\
46.0 \% \text { of Total }\end{array}$ & $\begin{array}{l}110 \\
44.7 \% \text { of Total }\end{array}$ & $\begin{array}{l}1.3 \% \text { difference } \\
\text { Not significant }(0.691)\end{array}$ \\
\hline Number Granted in Final & $\begin{array}{l}91 \\
52.3 \% \text { of Total }\end{array}$ & $\begin{array}{l}129 \\
52.4 \% \text { of Total }\end{array}$ & $\begin{array}{l}0.1 \% \text { difference } \\
\text { Not significant }(0.915)\end{array}$ \\
\hline Number Denied in Final & $\begin{array}{l}83 \\
47.7 \% \text { of Total }\end{array}$ & $\begin{array}{l}117 \\
47.6 \% \text { of Total }\end{array}$ & $\begin{array}{l}0.1 \% \text { difference } \\
\text { Not significant }(0.915)\end{array}$ \\
\hline
\end{tabular}

Table 4: Average Length of Time to Final Resolution for Applications Begun Each Year

\begin{tabular}{|l|l|l|}
\hline Year & Number of Applications & Average Months to Resolution \\
\hline 1995 & 1 & 24 \\
\hline 1996 & 2 & 23 \\
\hline 1997 & 4 & 17.75 \\
\hline 1998 & 2 & 9.50 \\
\hline 1999 & 6 & 7.33 \\
\hline 2000 & 3 & 5.67 \\
\hline 2001 & 8 & 4.80 \\
\hline 2002 & 8 & 12.22 \\
\hline 2003 & 3 & 3 \\
\hline
\end{tabular}

48 This reports the results of a t-test, testing whether the averages of the variables for the subset of applications with an initial application date given and the averages of the variables for the subset of applications with no application date given are significantly different. The value in brackets is the pvalue of the t-statistic. 


\begin{tabular}{|l|l|l|}
\hline Year & Number of Applications & Average Months to Resolution \\
\hline 2004 & 2 & 7.67 \\
\hline 2005 & 13 & 10.75 \\
\hline 2006 & 12 & 7.82 \\
\hline 2007 & 7 & 19.83 \\
\hline 2008 & 9 & 18 \\
\hline 2009 & 1 & 14.33 \\
\hline 2010 & 7 & 11.83 \\
\hline 2011 & 5 & 16.80 \\
\hline 2012 & 2 & 9 \\
\hline 2013 & 7 & 6 \\
\hline 2014 & 28 & 15.59 \\
\hline 2015 & 7 & 19.22 \\
\hline 2016 & 12 & 21.67 \\
\hline 2017 & 17 & 15.53 \\
\hline 2018 & 8 & 8.10 \\
\hline
\end{tabular}

\section{Applicant SuCCess}

To analyze trends in applicant success, we examined both the final disposition of applications, and their disposition at each level of court. We tracked over time the number of applications presently granted, the number presently denied, and the difference between those two variables. ${ }^{49}$ Figure 3 illustrates.

Figure 3: Difference Between Number of Applications

\section{Granted and Number Denied}

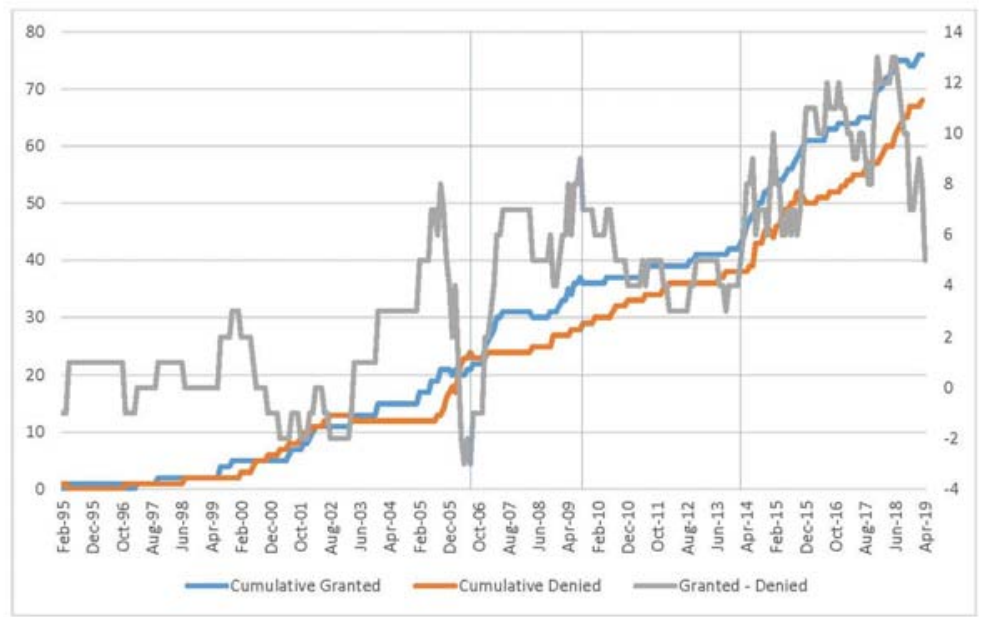

49 An application switches status if overturned on appeal. For example, if an application was granted by the Master, and this decision was overturned on appeal, as of the date of the appeal decision, the number of granted applications decreases by one (because now one less application has been granted) while the number of denied applications increases by 1 (because now one more application has been denied). The difference between Number Granted and Number Denied decreases by two. 
One can observe an increasing tendency to grant Drop Dead Applications from about June 2006 until about July 2009. The tendency to grant such applications then apparently declines until October 2013. With Rule 4.33 coming into force, there appears to be a significant increase in the tendency to grant them until at least the beginning of 2018.

The slope of the "Granted - Denied" line is the change in this value over time. It therefore indicates the tendency toward granting Drop Dead Applications (if positive) or toward denying them (if negative). During the period July 2009 through October 2013, the slope is $-0.058,{ }^{50}$ indicating a trend toward denying more applications. During the period of November 2013 through December 2017, the slope is $0.110,{ }^{51}$ indicating a trend toward granting more applications. An F-test of whether these two slopes are significantly different had a p-value of 0.000 , confirming the slopes are different at a 1 percent level of significance. We can conclude that leading up to the 2013 Amendment, there was a trend of denying more Drop Dead Applications. This trend reversed after the amendment.

We also observed that, prior to the 2013 Amendment, 60.0 percent of reported Drop Dead Applications were granted in the first instance but only 51.75 percent were granted in the final decision. Since the 2013 Amendment, this has reversed: 48.5 percent were granted at the first instance, and 53.5 percent in the final decision. We conclude that, upon Rule 4.33 coming into force, Masters continued the trend of granting fewer Drop Dead Applications. Justices have strongly reversed this trend, resulting in an increasing success rate for dismissal of an action.

We reviewed all reported decisions on Drop Dead Applications from January 2019 through May 2019 (five months). There were 17 reported decisions from all three levels of court. Ten of these decisions granted the application to dismiss the action - a 59 percent success rate. We conclude chances remain more likely than not that defendants will escape liability under a Drop Dead Application. ${ }^{52}$

\section{Propensity to APPEAL}

We counted the number of appealable decisions ${ }^{53}$ made each year, and the number of those decisions that were appealed to the next level of court. The results are given in Table 5. Table 6 provides multi-year averages leading up to the 2013 Amendment.

There was an apparent declining propensity to appeal up until the 2013 Amendment. Once the current form of the Drop Dead Rule was implemented, the appeal rate jumped from 25.00

A t-test of the statistical significance of this slope has a p-value of 0.000 , meaning it is statistically significant at the 1 percent level of significance.

A t-test of the statistical significance of this slope has a p-value of 0.000 , meaning it is statistically significant at the 1 percent level of significance.

Of the cases reviewed, Justice Bruce McDonald heard more of the Drop Dead Applications than any other Master or Justice. He, more often than not, found that the case had not been significantly advanced and supported dismissal of cases. Emphasis was put on the need for a functional approach as described in Nash v Snow, 2014 ABQB 355 [Nash]; Phillips, supra note 21; Ursa Ventures Ltd v Edmonton (City), 2016 ABCA 135 [Ursa Ventures]; Weaver v Cherniawsky, 2016 ABCA 152 [Weaver]; Ro-Dar Contracting, supra note 22 . Additionally, Justice McDonald wrote several times that the functional analysis as described in Morasch, supra note 19, should not be used. 
percent up to 46.15 percent, or three, four and five-year averages of 41.97 percent, 42.94 percent and 40.60 percent.

The average annual appeal rate for the five years prior to the 2013 Amendment (that is, 2009 through 2013) is 31.08 percent. The average annual appeal rate for the five years since the 2013 Amendment (that is, 2014 through 2018) is 40.60 percent. A t-test of whether these averages are statistically different has a p-value of 0.000 . We therefore conclude the appeal rate of Drop Dead Applications increased upon the 2013 Amendment coming into force. We are unaware of any other circumstances that may explain the increase in appeals.

To summarize again, the data reveals the Consequences of the 2013 Amendment are:

1. there are significantly more Drop Dead Applications;

2. Drop Dead Applications are taking significantly longer to achieve final resolution;

3. significantly more Drop Dead Applications result in the dismissal of a claim; and

4. $\quad$ significantly more Drop Dead Applications are appealed. ${ }^{54}$

TABle 5: Number of APPEAlable

DECISIONS AND APPEALS EACH YEAR

\begin{tabular}{|l|c|c|c|}
\hline Year & $\begin{array}{c}\text { Number of } \\
\text { Appealable Decisions }\end{array}$ & $\begin{array}{c}\text { Number of } \\
\text { Appeals }\end{array}$ & Percentage Appealed \\
\hline 1995 & 5 & 3 & $60.00 \%$ \\
\hline 1996 & 3 & 2 & $66.67 \%$ \\
\hline 1997 & 8 & 8 & $100.0 \%$ \\
\hline 1998 & 7 & 1 & $14.29 \%$ \\
\hline 1999 & 11 & 4 & $36.36 \%$ \\
\hline 2000 & 8 & 2 & $25.00 \%$ \\
\hline 2001 & 14 & 4 & $28.57 \%$ \\
\hline 2002 & 16 & 4 & $25.00 \%$ \\
\hline 2003 & 4 & 1 & $25.00 \%$ \\
\hline 2004 & 4 & 0 & $0.000 \%$ \\
\hline 2005 & 15 & 9 & $60.00 \%$ \\
\hline 2006 & 20 & 10 & $50.00 \%$ \\
\hline 2007 & 19 & 8 & $42.11 \%$ \\
\hline 2008 & 6 & 4 & $66.67 \%$ \\
\hline 2009 & 12 & 5 & $41.67 \%$ \\
\hline 2010 & 10 & 3 & $30.00 \%$ \\
\hline 2011 & 9 & 4 & $44.44 \%$ \\
\hline 2012 & 7 & 1 & $14.29 \%$ \\
\hline 2013 & 8 & 2 & $25.00 \%$ \\
\hline 2014 & 26 & 12 & $46.15 \%$ \\
\hline & & & \\
\hline
\end{tabular}




\begin{tabular}{|l|c|c|c|}
\hline Year & $\begin{array}{c}\text { Number of } \\
\text { Appealable Decisions }\end{array}$ & $\begin{array}{c}\text { Number of } \\
\text { Appeals }\end{array}$ & Percentage Appealed \\
\hline 2015 & 28 & 13 & $46.43 \%$ \\
\hline 2016 & 15 & 5 & $33.33 \%$ \\
\hline 2017 & 24 & 11 & $45.83 \%$ \\
\hline 2018 & 32 & 10 & $31.25 \%$ \\
\hline
\end{tabular}

Table 6: AVerage Appeal Rate

OF DROP DEAD DECISIONS*

\begin{tabular}{|c|c|}
\hline Time Period & Average Appeal Rate \\
\hline 2005 through 2013 & $41.57 \%$ \\
\hline 2006 through 2013 & $39.27 \%$ \\
\hline 2007 through 2013 & $37.74 \%$ \\
\hline 2008 through 2013 & $37.01 \%$ \\
\hline 2009 through 2013 & $31.08 \%$ \\
\hline 2010 through 2013 & $28.43 \%$ \\
\hline 2011 through 2013 & $27.91 \%$ \\
\hline
\end{tabular}

*Note: Given the high volatility from year to year, shorter-term averages are less reliable indicators of trend.

\section{Why The CONSEQUENCES?}

To determine root causes, we must first consider interactions between the Consequences. If applicants have any sense of the greater success suggested in reported decisions, they will recognize the high potential for benefit from pushing the application compared to small potential cost. Thus, the new tendency of appeal courts to grant more applications may be a cause of increased appeals.

The increased number of appeals and of applications together increase strain on already scarce judicial resources. As strain increases, it takes longer to have applications heard and longer to receive the court's decisions. Add to this the natural consequence that appeals take time, and we can explain the longer time to resolution. Figure 4 illustrates these interactions. 
FiguRE 4: INTERACTIONS BETWEEN CONSEQUENCES AND CAUSES

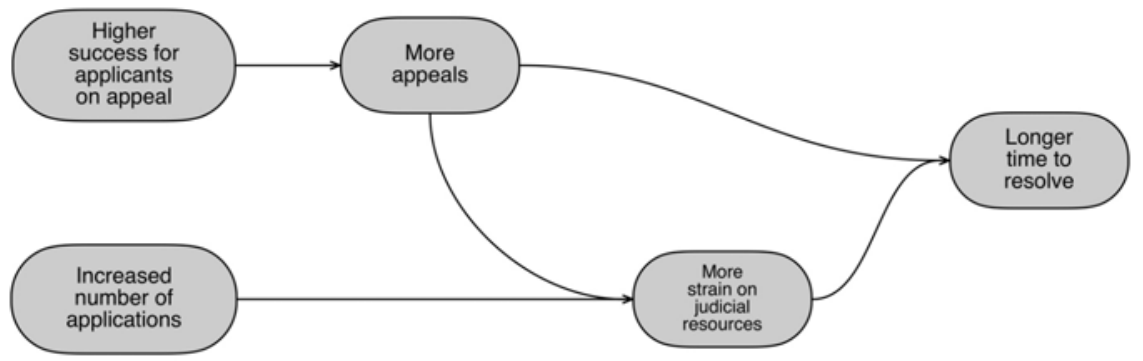

As a final root cause, it is safe to presume any uncertainty or disagreement about how Rule 4.33 does, or should, operate would also increase the appeal rate.

From this reasoning, to explain the Consequences, we need to explain:

1. uncertainty about Rule 4.33;

2. the increased applicant success; and

3. the increased number of applications.

\section{A. UnCERTAINTY ABOUT RULE 4.33}

Changing the wording of the Rule would naturally raise speculation as to whether it also changed application. ${ }^{55}$ But more than this, judicial decisions exhibited uncertainty and even conflict during the switch from the Morasch Analysis to a new jurisprudence.

As explained above, the Morasch Analysis under Rule 244.1 gave an automatic pass to any procedural step required by the Rules, and any other "thing" was assessed for material advancement toward trial. Under the 2010 Amendments, this same Analysis was employed, with neither the change from "material" to "significant" nor the addition of the Foundational Rules impacting outcomes.

Initial decisions under Rule 4.33 continued the same jurisprudence. For example, Master Hanebury in Krieter explained, "[d] espite these changes, the principles found in previously determined case law continue to be applicable." ${ }^{56}$ The Morasch Analysis was applied.

Justice Topolniski, in her 12 June 2014 decision in Nash, was the first to propose a difference. ${ }^{57}$ She removed the automatic pass for required procedural steps, determining that, since the 2013 Amendment removed any reference to "step" or "thing," a Functional Analysis is always required. ${ }^{58}$ Some immediately adopted this Nash Analysis. ${ }^{59}$ Others either

\footnotetext{
55 After all, the courts had previously identified the presumption that a word change indicates a change in meaning.

Supra note 43 at para 14.

Supra note 52 .

Ibid at para 42.

The next day, Justice Crighton cited it with approval in Steparyk v Alberta, 2014 ABQB 367 at para 7.
} 
were not aware of the decision, disagreed with it and so continued to cite the Morasch Analysis, ${ }^{60}$ or fit the new concepts into the old jurisprudence. ${ }^{61}$

Despite opportunities, ${ }^{62}$ the Court of Appeal did not address the issue until almost two years after the Nash decision, with the 22 April 2016 decision in Ro-Dar Contracting. ${ }^{63}$ In that decision, the Court of Appeal approved of the Nash Analysis and required mandatory application of a Functional Analysis in Drop Dead Applications,${ }^{64}$ with a focus on significant advance toward resolution rather than toward trial. ${ }^{65}$

Further review of decisions reported in the first five months of 2019 displayed similar results. Each case was reviewed based on its unique circumstances, with the significance of any advance being determined in the closed environment of that case. Advances made are measured against a high bar.

It is significant that the new analysis of Drop Dead Applications did not emerge until after the Supreme Court of Canada decision in Hryniak. ${ }^{66}$ In that case, the Supreme Court expressly advocated for a "culture shift" in litigation toward alternative methods of resolving disputes. We agree with Billingsley that this mandate influenced subsequent interpretation of Rule 4.33: "The Hryniak case has emboldened Alberta courts to demand that litigants and counsel comply with Rule 1.2 by focusing on the function of litigation procedures in achieving an end to the dispute, rather than emphasizing the formalities of litigation process." ${ }^{67}$ This is inherently ambiguous:

\footnotetext{
It is an entirely different exercise, however, to identify the procedural steps which are proportional to resolution when the resolution options themselves vary widely. Without a clear resolution target, reasonability and proportionality of process can only be determined, if at all, after the fact. This leaves litigants and counsel with little guidance, at the time when procedural decisions must be made, as to whether their procedural choices will satisfy the culture shift requirement of proportionality. ${ }^{68}$
}

\section{B. InCREASED APPLICANT SUCCESS}

Increased applicant success would be a natural result if courts now place higher expectations on plaintiffs apart from the reduction of the time window from five years to three. This higher bar is in fact seen in the mandated Nash Analysis and the requirement that disputes now be significantly advanced to resolution rather than simply trial.

It should again be emphasized that the Functional Analysis in the Nash Analysis is not the same as the Functional Analysis referenced in the Morasch Analysis. The most obvious

\footnotetext{
See e.g. Whyew, supra note 44.

See e.g. Huerto $v$ Canniff, 2014 ABQB 534 at para 42.

See e.g. Steparyk $v$ Alberta, 2015 ABCA 125, aff'g 2014 ABQB 367.

Supra note 22.

Ironically, since this time, courts have referred to the Foundational Rules to justify this new analysis, rather than Justice Topolniski's original point that reference to "step" or "thing" was eliminated. This ignores the fact that the Foundational Rules existed beginning in 2010, yet the Nash Analysis did not appear for another 4 years.
}

Billingsley, supra note 9 at 21.

Supra note 7.

Billingsley, supra note 9 at 27.

Ibid at 28-29. 
indicator of this conclusion is that lists of sufficient steps are discouraged. ${ }^{69}$ Further, under the Morasch Analysis, a court was to assess each proposed "thing," independently of any other "thing," to determine whether that one "thing" materially advanced the action toward trial. The Nash Analysis instead uses a "macro view":

Put another way, the court must view the whole picture of what transpired in the three-year period, framed by the real issues in dispute, and viewed through a lens trained on a qualitative assessment. This necessarily involves assessing various factors including, but not limited to, the nature, value and quality, genuineness, timing, and in certain circumstances, the outcome of what occurred. ${ }^{70}$

The Court of Appeal approved of this macro view, ${ }^{71}$ emphasizing that "[w]hile any application under the drop dead rule must obviously have regard to what was done to advance the litigation, it would be a step backwards if the search for 'steps' or 'things' was now replaced by a search for '[o]ccurrences." "72 To summarize, this new Functional Analysis is not a methodical assessment of each "step," "thing," or "occurrence" to determine whether any such event, on its own, significantly advanced the action. Rather, the courts are to look at the three-year window to determine whether any event on its own, or in cumulation with other events, significantly advances the action.

Continued misunderstanding of this difference in the Functional Analysis likely contributes to the confusion explained above. Numerous cases since Nash and Ro-Dar have continued to assess each "thing" independently without consideration of the cumulative effect. Only recently do we have consistent, clear acknowledgment of the need to assess events collectively. ${ }^{73}$

While cumulative consideration should make things easier for plaintiffs, there is also a new emphasis on the uniqueness of each case. A "significant advance" is observed in the specific context of each case. As explained in Weaver, "each piece of litigation is unique and the content, value, and timing of the advance in the action said to 'reset the clock' for the purposes of rule 4.33 must be assessed within the context of that lawsuit. This is the heart of the functional approach." 74

Lefebvre and MacKay stress this departure from reliance on procedural steps and state that "[n]ow, the analysis is heavily based on the individual facts of a given action. A step taken in the course of one litigation may significantly advance the action, but the exact same step in a different case may not." 75 Gone are the days that plaintiff's counsel can take a previously judicially sanctioned step and safely diarize the action. Instead, they are left wondering whether, in this particular case, has enough been done?

This is further complicated in that any significant advance must bring the action closer to resolution, not necessarily trial. One might think that any procedural step brings an action

See e.g. Paul Rains Design Build Ltd v Choma, 2019 ABQB 187 at para 12.

Supra note 52 at para 30 [emphasis added].

Ro-Dar Contracting, supra note 22 at para 15.

Ibid.

See e.g. Alghazawi v Alberta, 2019 ABQB 208 at paras 2-3 [Alghazawi].

Supra note 52 at para 21.

Lefebvre \& MacKay, supra note 14. 
closer to resolution because, until an affidavit of records (for example) is provided, questionings (that might illuminate a possible resolution) cannot be scheduled. Therefore, any affidavit of records, whether fulsome or boilerplate, advances a claim because trial is now one step closer. However, referring to the Foundational Rules, courts are pushing resolutions other than trial. The presumption is that trial is not the most fair, just, timely, and cost-effective court process for resolution. Under the Nash Analysis, filing an affidavit of records containing repetitive or unimportant documents may be nothing more than a procedural step that brings no depth to questionings. It does not assist in advancing any alternative resolution method such as mediation, summary judgment, or summary trial. The challenge here is a paradigm shift — methodical plodding toward trial, attempting settlement along the way, is a thing of the past. In the spirit of Hryniak, counsel must assess what other resolution mechanism will bring a faster and cheaper end to the dispute and pursue it.

To qualitatively analyze the impact the Nash Analysis has had on Rule 4.33 decisions, we reviewed every Alberta Court of Appeal decision reported to the end of 2018, all Alberta Court of Queen's Bench decisions that were judicially considered at least five times by May 2019 , and all Rule 4.33 decisions reported in the first quarter of 2019. This resulted in a review of over 60 judgments, through which we composed a list of what events, or culmination of events, were considered to significantly advance an action and what events were considered not to. See the Appendix for a full listing of cases and events that were either considered to significantly advance an action or not significantly advance an action. ${ }^{76}$ However, we want to again emphasize the substance of the Nash Analysis, which looks at the specific facts of each case. By no means are the results that follow to be considered a steadfast directive for determining a significant advance. Rather, they allow comparison of expectations before the 2013 Amendment and after. To this end, we also reviewed all cases from 2005 to 2011 that considered the Drop Dead Rule prior to the 2010 Amendments. This resulted in a review of 36 cases. The Appendix contains 3 tables: Table 7 provides a summary analysis of Rule 244.1 applications (2005-2011), Table 8 provides a similar analysis for Rule 15.4 applications during the Transition Period (2010-2013), and Table 9 provides the summary analysis of Rule 4.33 decisions (2013-2019). ${ }^{77}$

While the summary analysis of Rule 4.33 decisions provides some insights into expected outcomes in certain situations, it also highlights the fact-specificness of each ruling and the emphasis on a Functional Approach. Nevertheless, a few key points can be derived, particularly in comparison to the summary analysis of Rule 244.1:

1. Pleadings - Higher Standard. As a procedural step required by the Rules, pleadings were always deemed a step that materially advanced the action. Under Rule 4.33, however, boilerplate pleadings will likely not be considered a significant advance. $^{78}$

2. Settlement Discussions - No Significant Difference. It could be seen as a significant advance if the discussion narrows issues, ${ }^{79}$ depending on how it conjoins 
with other events. A settlement offer can be evidence that other efforts were valuable ${ }^{80}$ but on its own must provide information or narrow issues. ${ }^{81}$

3. Retention of Experts - Higher Standard. Prior to the 2013 Amendment, if experts were retained and that retention was communicated to the other party, it was generally considered a material advance. ${ }^{82}$ Rule 4.33 seems to now additionally require that information be obtained from the experts. ${ }^{83}$

4. Affidavits - Insufficient information before the 2013 Amendment. However, in Haekel v. Canada, the Courts confirmed that an affidavit that is required to be filed before proceeding to trial would be considered something that materially advances an action. ${ }^{84}$ Under Rule 4.33, affidavits filed and served that provide relevant information and affidavits cross-examined on may be considered significant advances. $^{85}$

5. Affidavits of Records - Higher Standard. Prior to the 2010 Amendments, affidavits of records were considered to materially advance an action if they contained relevant information. ${ }^{86}$ Following the 2013 Amendment, not only must they contain relevant information, they must also contain documents that narrow the issues or provide information that was not previously known. This can be varied by whether the documents were previously available, ${ }^{87}$ and their nature and quality. ${ }^{88}$

6. Answers to Undertakings - No Significant Difference. Both under Rule 244.1 and under Rule 4.33, answers to undertakings that contain more than perfunctory answers are more likely to be seen as a material or significant advance; ${ }^{89}$ however, the requirement for substantive answers seems to be stricter under Rule 4.33.

7. Pre-Trial Conference - Higher Standard. Under Rule 244.1, attendance at a pretrial conference was considered to materially advance an action. Since the 2013 Amendment, the pre-trial conference must also result in something more than a procedural step or agreement on housekeeping matters to be considered a significant advance..$^{90}$ Actual attendance at a judicial dispute resolution will be considered a significant advance.

See 1406998 Alberta Ltd v Dorbandt, 2018 ABCA 213 at para 2.

See Brace $v$ McKen, 2019 ABCA 135 at paras 20-21.

See Mohacsi $v$ J Folk \& Associates Ltd, 2006 ABQB 170 at para 30.

See Huerto $v$ Canniff, 2015 ABCA 316 at para 10 [Huerto CA].

2008 ABQB 701 at para 50.

See Vander Griendt v Canvest Capital Management Corp, 2014 ABQB 542 at para 103.

See Kent Construction Services Ltd v Plasco Construction Ltd, 2007 ABQB 355 at para 20.

See XS Technologies Inc $v$ Veritas DGC Land Ltd, 2016 ABCA 165 at paras 16-17.

See Huerto CA, supra note 83 at para 14.

See M L Bruce Holdings Inc v Ceco Developments Ltd, 2015 ABQB 604 at para 34.

See Weaver, supra note 52 at para 22. 
8. Applications - Higher Standard. Previously, an application that was heard was considered a material advance. ${ }^{91}$ Since the 2013 Amendment, the application must narrow or define issues for trial to be considered a significant advance. ${ }^{92}$

9. Notice to Admit/Disclose - Higher Standard. Notices were considered to materially advance a claim under Rule 244.1, even if replies had not been supplied..$^{93}$ Under Rule 4.33 , these likely will not be considered significant advances unless there are substantive replies. ${ }^{94}$

10. Other Litigation - No Significant Difference. Throughout the existence of the Drop Dead Rule, relying on advances in other litigation is difficult, and requires proof that the two actions are inextricably linked. ${ }^{95}$

11. Standstill Agreements - No Significant Difference. Under all forms of the Rule, express standstill agreements exempted the relevant period of time from the application of the Drop Dead Rule.

The most substantial differences from before and after the 2013 Amendment are in court applications, notices, and pre-trial conferences. Prior to the 2013 Amendment, courts often found these "things" materially advanced the claim because they completed a procedural step. Since the rise of the Nash Analysis, plaintiffs much reach a higher bar to prove a significant advance and can no longer rely on required procedural steps. The action must advance in a meaningful way toward resolution.

The result is that plaintiffs have greater difficulty avoiding dismissal under the Drop Dead Rule. There is no longer a clear list identifying what qualifies as a significant advance and what does not. Counsel must always seek steps leading to a more timely and cost-effective resolution.

\section{INCREASED APPLICATIONS}

We considered four hypotheses as to why applications have increased.

1. The shortened time frame created a temporary flood of applications for actions that would have been dismissed after five years anyway.

2. ALIA has proposed the increased number of applications is due to the 2009 economic downturn and plaintiffs therefore being unable to finance their claims; $;^{96}$

3. Defendants anticipate the new language and shorter time period would increase success.

See 155569 Canada Limited v 57618 Manitoba Ltd, 2006 ABQB 919 at para 13.

See Alberta $v$ Cox, 2017 ABCA 5 at para 25.

See Kapicki $v$ Kapicki, 2010 ABQB 615 at paras 12-13.

See Krieter, supra note 43 at paras 27-28.

See Bahcheli, supra note 31; see also Chisan, supra note 23.

Law Society of Alberta, supra note 8. 
4. Increasing success rates with little repercussions to defendants compared to the benefit obtained on success is attractive.

We find all four hypotheses have some validity, but do not fully explain the sharp increase in applications.

We find the first hypothesis is the most logical explanation and accounts for the largest portion of the increase. Previously in this article, we reported an estimated trend for the normal level of applications each year. The estimated trend does not consider the decreased time frame; rather, it is based on what would have happened had no amendment occurred. With the 2013 Amendment, applications could be made for claims that had been stale for five years, four years, and three years. This means the estimated 5.65 applications for 2014, the estimated 5.74 applications for 2015, and the estimated 5.83 applications for 2016 immediately became relevant. Because of this shortening of the timeframe, we would anticipate 18 applications (rounding up from 17.22) in the first year of the 2013 Amendment, simply because of the shortened time frame. We would then anticipate about six applications in each year thereafter.

Comparing this to the actual number of applications, we still have ten unexplained applications in 2014, one in 2015, six in 2016, and 11 in 2017. The other three hypotheses help explain some of these extra applications.

The 2009 recession was four years before the 2013 Amendment. Therefore, it was not until Rule 4.33 came into force that its full impact could be felt. Even so, we could expect it to affect litigation that stalled prior to the recession itself. We would therefore expect to see more applications than normal prior to the 2013 Amendment.

There was a jump in the number of applications from two in 2012 to seven in 2013. This may indicate the 2009 recession had some impact. We conclude, however, that the impact is likely minor. Jumps like this happened in other years (2004 to 2005 saw a jump from two to 13); seven was not extraordinarily higher than the estimated normal (5.57 for 2013) whereas two was extraordinarily low.

In addition, ALIA's economic argument would also have to apply to defendants. Defendants also bear costs when bringing a Drop Dead Application and, even if costs are awarded on the success of such an application, they likely do not cover solicitor-client costs. As defendants are not immune to economic downturns, we could expect they would be hampered in making such applications. We therefore conclude that the economic downturn had a minor impact on the number of applications. It is insufficient to explain the remaining 28 extra applications.

Similarly, curiosity as to the interpretation of the new language likely explains a small portion of the increased applications. All initial decisions stated the analysis as before. The Nash Analysis did not come out until eight months after the 2013 Amendment. Though it clearly raised the bar for plaintiffs, creating more opportunity for defendants, decisions at first instance continued the trend of denying more applications. As far as reported decisions indicated, increased success was to be found only on appeal - which takes longer to be determined. 
Initial reliance on the old jurisprudence and the failures in first instance likely discouraged defendants and may explain the drop from 28 applications in 2014 to seven in 2015 . As applicants succeeded on appeal and the Nash Analysis gained acceptance, it may have encouraged the subsequent increases in applications. It is likely, then, that increased success has prompted additional applications.

We conclude these four hypotheses explain the majority of the increased applications.

\section{IMPACT ON FOUNDATIONAL OBJECTIVES}

What kind of impact is the increase in applications, and the success of such applications, having on plaintiffs, their counsel, their counsel's insurance, and the court system? Based on the Foundational Rules, the Drop Dead Rule is supposed to be a court process provided to fairly and justly resolve claims in a timely and cost-effective way. ${ }^{97}$ We must therefore consider the impact of the Consequences on fairness and justice, and on timeliness and costeffectiveness.

\section{A. FAIRness ANd Justice}

The Drop Dead Rule is intended to end actions "so inactive that they should be deemed to have been abandoned." 98 Given its inclusion in the Rules, we must presume such an outcome is considered fair and just - if such "dead" actions are all the Rule catches. As addressed in our discussion of ALIA's hypothesis for the increase in Drop Dead Applications, however, some claims are being dismissed because the plaintiff is impecunious, not because of abandonment. Using time as the sole measure of abandonment means penurious plaintiffs are more likely to have legitimate claims dismissed than plaintiffs with means. This problem is exacerbated by the fact that only defendants are eligible to apply for legal aid, not plaintiffs. Research is needed to determine the full extent of this inequitable effect.

We also question the fairness and justice of putting full responsibility on plaintiffs to maintain momentum toward resolution. ${ }^{99}$ While the Foundational Rules are cited to prohibit defendants from purposely obstructing or delaying an action, ${ }^{100}$ the incentive remains to find tactics for stalling that escape court scrutiny. Plaintiffs may apply to the court for assistance to move matters forward, but such applications contribute to delay in resolution, add expense, and further strain thin court resources. Such situations suggest again that mandatory dismissal based solely on time creates unfair and unjust outcomes.

\section{B. TIMELINESS AND COST-EFFECTIVENESS}

We also conclude the 2013 Amendment and subsequent Nash Analysis does not contribute to timely and cost-effective outcomes. The significant increase in the number of

99 Janstar Homes Ltd v Elbow Valley West Ltd, 2016 ABCA 417, reiterates that the Foundational Rules do not change the point that plaintiffs have full responsibility to keep a dispute moving forward. 
Drop Dead Applications and the number that are appealed means more court and lawyer resources are used to resolve these applications than before. This is expensive, and takes resources away from resolving other disputes. ${ }^{101}$ Further, the length of time to resolve Drop Dead Applications is significantly longer. While successful applications are still determined more quickly than if the litigation were permitted to succeed, more delay is created for unsuccessful applications. Given that a Drop Dead Application often stops any other progress in a dispute, unsuccessful applications delay resolution, on average by 18 months. We can compare the positive effect of a quicker end to litigation with successful Drop Dead Applications with the negative effect of a slower end to litigation with unsuccessful applications.

There are 1.75 percent more successful applications. Thus, 1.75 percent of lawsuits are now resolved faster than prior to the 2013 Amendment (or, on average, 0.25 lawsuits each year). There would have been 51.75 percent of applications granted under Rule 244.1 and under Rule 4.33. Under Rule 4.33, these applications take, on average, five months longer to resolve. These 7.45 lawsuits each year are delayed by the new Drop Dead Rule. In addition, 46.5 percent of applications are denied. These lawsuits also take, on average, five extra months before returning to progress upon resolution of the Drop Dead Applications. This accounts for 6.70 lawsuits each year. In sum, the changes to the Drop Dead Rule have resulted in faster resolution of 0.25 lawsuits each year, but have delayed resolution of 14.15 lawsuits each year. This adds up to a total delay of 5.9 years in each year. The 0.25 lawsuits that are resolved more quickly will have to have been shortened by more than 23.6 years to result in a net gain.

One may deduce that if more than half of Rule 4.33 applications end in a dismissal of an action, there may be an increase in corresponding complaints to the Law Society of Alberta and claims against lawyers for negligence. Even the serving of the Drop Dead Application turns plaintiff's counsel to the insurer to handle. This increases insurance costs, and the resources spent handling Law Society complaints. Further research and survey with the counsel that have represented in these applications could determine the actual resources consumed. We may infer, however, that tens of thousands of dollars have been paid by plaintiffs, defendants, and taxpayers to conclude Rule 4.33 applications.

We therefore conclude the 2013 Amendment and Nash Analysis have acted contrary to the Foundational Objectives. It results in some resolutions that are unfair and unjust, and increases the cost and length of many legal disputes.

\section{RECOMMENDATIONS}

There is an obvious need for a procedural rule that extinguishes a claim where a plaintiff has abandoned the claim by delay, but not extended the courtesy of officially discontinuing the action. However, how can the Drop Dead Rule better suit its name while still being fair and just to the parties involved, and also decreasing cost and time? 
The first problem is that the Drop Dead Rule is based solely on a time constraint. If three years have passed without a significant advance, the action must be dismissed unless one or more limited exceptions apply.

This could be resolved by softening mandated dismissal and permitting court discretion, based on factors such as explanations for the delay and the defendant's behaviour. However, this quickly turns into the Long Delay Rule (Rule 4.31) with a shorter time horizon. Furthermore, uncertainty in how discretion will be exercised would cause further confusion and delay until clear guidance was established. A better approach may be to expand the considerations or exceptions before dismissal is mandated.

The second problem with the Drop Dead Rule is that all responsibility is put on the plaintiff. This could be resolved by adding exceptions explicitly based on defendant behaviour, beyond standstill agreements.

The third problem is that the Functional Approach and shorter time period are creating delay and cost. We may yet see this settle down as plaintiffs become accustomed to the higher standard. This could be assisted by providing counsel with clearer guidelines on the operation and application of the Drop Dead Rule as this article does. Delay and cost could also be assisted by requiring the applications be made by written argument only, with no oral argument. This would reduce consumption of court resources.

Adapting similar procedures to situations of a rejected formal offer to settle may be the simplest solution. Rule 4.29(1) of the Rules states:

Subject to subrule (4), if a plaintiff makes a formal offer to settle that is not accepted and subsequently obtains a judgment or order in the action that is equal to or more favourable to the plaintiff than the offer, the plaintiff is entitled to double the costs to which the plaintiff would otherwise have been entitled. ${ }^{102}$

This rule applies consequences to a party who has failed to conclude an action "in a timely and cost-effective way" by "facilitat[ing] the quickest means of resolving a claim at the least expense" and settling the claim "as early in the process as practicable."103 These consequences encourage a party to sincerely consider a formal settlement offer instead of rushing to court and abusing resources.

The surge in Drop Dead Applications may also be reduced by applying the same cost consequences. If an applicant is unsuccessful, the plaintiff could be awarded double costs forthwith. To make this effective, an order of "costs in the cause" should be unavailable. Drop Dead Applications do not apply to the merit of the case and therefore should not be connected to the cause. With the risk of double costs, defendants may be more careful in bringing a Drop Dead Application. If this is combined with an amendment to consider specific defendant behaviour or other explanations for delay, there may be increased plaintiff and defendant cooperation to resolve disputes in a timely and cost-effective way that is fair and just to both parties. 


\section{Conclusion}

Quantitative and qualitative analyses reveal the Consequences of the current judicial approach to Drop Dead Applications, the reasons for those Consequences, and the impact on parties, the court process, and society. Thorough investigation demonstrates that, since the 2013 Amendment (and likely the Hryniak decision) prompted a revised process for adjudicating Drop Dead Applications, the number of applications has significantly increased, these applications take longer to achieve final resolution, more applications are granted, and significantly more are appealed. We conclude that the Consequences have detracted from the Foundational Objectives rather than helped achieve them, thereby failing the acid test as described by the ALRI.

Uncertainty about how Drop Dead Applications are decided contributes to these outcomes. Courts have had difficulty coming to a consensus on a clear and uniform approach. This new approach is inherently hazy. The emphasis on the fact-specificness of each outcome means counsel gains limited guidance from precedents.

The shortened time frame from three to five years has been the primary cause of the increase in applications. Increased success for applicants is likely the second most important factor, followed by economic conditions. The higher success rate is largely attributable to the higher standard placed on plaintiffs. Plaintiffs maintain full responsibility to achieve significant advances toward the most timely and cost-effective resolution.

Using time as the sole criterion for mandating dismissal and limiting the exceptions to the Drop Dead Rule means these consequences have an inequitable negative impact on impecunious plaintiffs. The approach also increases the time and cost of resolving a majority of applications, with spill-over effects to other disputes. We therefore conclude that the new Drop Dead Rule and its associated jurisprudence detract from the Foundational Objectives.

As analogous claim-ending rules exist in other jurisdictions across Canada, this research can assist similar analyses in those jurisdictions. These results are important for assessing whether an important part of rules for court processes is achieving the goal intended. In Alberta, revisions to the Drop Dead Rule are needed to ensure outcomes truly are fair, just, timely, and cost-effective. 


\section{APPENDIX}

TABLE 7: SUMmary ANALYSIS

of CASES FRom RULE 244.1(1) APPLiCATIONS

\begin{tabular}{|c|c|c|}
\hline Citation & Decision & Reasons for Judgment \\
\hline \multicolumn{3}{|c|}{ Affidavit of Records/Supplemental Affidavit of Records } \\
\hline $\begin{array}{l}\text { Reimer v. Simms, } 2006 \text { ABQB } \\
326\end{array}$ & $\begin{array}{l}\text { Not a Material } \\
\text { Advance }\end{array}$ & $\begin{array}{l}\text { Filing and Serving an Affidavit of Records } \\
\text { "The voluntary filing of an affidavit of records is not a } \\
\text { "thing"' (para 31). }\end{array}$ \\
\hline $\begin{array}{l}\text { Sinnott v. Canadian Pacific } \\
\text { Railway Company, } 2010 \mathrm{ABQB} \\
185\end{array}$ & Material Advance & $\begin{array}{l}\text { Filing and Serving an Affidavit of Records } \\
\text { "Time was tacked on so that the five-year period began } \\
\text { in August 2003. The Affidavit of Records was filed } \\
\text { within the five year period" (para 12). }\end{array}$ \\
\hline $\begin{array}{l}\text { Kent Construction Services Ltd. } \\
\text { v. Plasco Construction Ltd., } \\
2007 \text { ABQB } 355\end{array}$ & $\begin{array}{l}\text { Not a Material } \\
\text { Advance }\end{array}$ & $\begin{array}{l}\text { Production of Documents } \\
\text { "Had the plaintiff brought an application for further and } \\
\text { better production, this document would not have been } \\
\text { central to its application. It is only an incomplete } \\
\text { overview of some of the underpinning documentation } \\
\text { that the plaintiff needed to assess the extras and back } \\
\text { charges that should be considered when determining the } \\
\text { ultimate amount to which it was entitled. Its provision } \\
\text { did not move the matter closer to trial in a meaningful } \\
\text { way" (para 22). }\end{array}$ \\
\hline $\begin{array}{l}\text { Kurian v. Alberta (Motor } \\
\text { Vehicle Accident Claims Act, } \\
\text { Administrator), } 2007 \text { ABQB } 369\end{array}$ & $\begin{array}{l}\text { Not a Material } \\
\text { Advance }\end{array}$ & $\begin{array}{l}\text { Affidavits of Disclosure } \\
\text { "Generally, documents provided under previous } \\
\text { commitments are not considered to be things that } \\
\text { materially advance the action" (para 66). }\end{array}$ \\
\hline \multicolumn{3}{|c|}{ Settlement Offers/Meetings } \\
\hline $\begin{array}{l}\text { Reimer v. Simms, } 2006 \text { ABQB } \\
326\end{array}$ & $\begin{array}{l}\text { Not a Material } \\
\text { Advance }\end{array}$ & $\begin{array}{l}\text { Settlement Discussions } \\
\text { "It has been held that settlement discussions do not } \\
\text { qualify as a "thing"” (para 31). }\end{array}$ \\
\hline \multicolumn{3}{|c|}{ Questionings \& Answers to Undertakings } \\
\hline $\begin{array}{l}\text { Barnes v. RBC Dominion } \\
\text { Securities Inc., } 2006 \text { ABQB } 290\end{array}$ & $\begin{array}{l}\text { Not a Material } \\
\text { Advance }\end{array}$ & $\begin{array}{l}\text { Answers to Undertakings } \\
\text { "Answering undertakings does not materially advance } \\
\text { the action, unless it involves the provision of a number } \\
\text { of critical documents" (para 38). }\end{array}$ \\
\hline $\begin{array}{l}\text { Reimer v. Simms, } 2006 \text { ABQB } \\
326\end{array}$ & Material Advance & $\begin{array}{l}\text { Answers to Undertakings } \\
\text { "This decision makes it clear that, in some } \\
\text { circumstances, the answering of undertakings can be a } \\
\text { 'thing' that materially advances the action" (para 36). }\end{array}$ \\
\hline $\begin{array}{l}\text { Ravvin Holdings Ltd. v. Ghitter, } \\
2008 \text { ABCA } 208\end{array}$ & Material Advance & $\begin{array}{l}\text { Answers to Undertakings } \\
\text { "[A] response to an undertaking is generally a thing that } \\
\text { advances an action, unless it is perfunctory or designed } \\
\text { to thwart, rather than advance, resolution of the } \\
\text { litigation" (para 30). }\end{array}$ \\
\hline
\end{tabular}




\begin{tabular}{|c|c|c|}
\hline Citation & Decision & Reasons for Judgment \\
\hline \multicolumn{3}{|c|}{ Questionings \& Answers to Undertakings (continued) } \\
\hline $\begin{array}{l}\text { Leder v. Karoles, } 2009 \text { ABQB } \\
334\end{array}$ & Material Advance & $\begin{array}{l}\text { Answers to Undertakings } \\
\text { "All undertakings have now been answered and in my } \\
\text { view, the answers although brief are not perfunctory" } \\
\text { (para 6). }\end{array}$ \\
\hline $\begin{array}{l}\text { Wagner v. Petryga, } 2009 \text { ABQB } \\
385\end{array}$ & Material Advance & $\begin{array}{l}\text { Answers to Undertakings } \\
\text { "In light of Ravvin I conclude that the answers to the } \\
\text { undertakings provided by the Plaintiff in } 2004 \text { were a } \\
\text { 'thing' that materially advanced the action" (para 37). }\end{array}$ \\
\hline $\begin{array}{l}\text { Nelson v. Emsland, } 2008 \text { ABCA } \\
387\end{array}$ & $\begin{array}{l}\text { Not a Material } \\
\text { Advance }\end{array}$ & $\begin{array}{l}\text { Service of Notice of Appointment for Examinations for } \\
\text { Discovery } \\
\text { "We also conclude that service of the appointment for } \\
\text { examination for discovery, in this case, is not a "thing" } \\
\text { that materially advanced the counterclaim. In order to } \\
\text { materially advance an action, the step taken must move } \\
\text { the action forward in a meaningful way" (para 14). }\end{array}$ \\
\hline $\begin{array}{l}\text { Haekel v. Canada, } 2008 \text { ABQB } \\
701\end{array}$ & $\begin{array}{l}\text { Not a Material } \\
\text { Advance }\end{array}$ & $\begin{array}{l}\text { Serving Producible Documents } \\
\text { "In the circumstances, I find that delivery of the } \\
\text { transcripts did not constitute a "thing" for the purpose of } \\
\text { Rule } 244.1 \text { that materially advanced the action as against } \\
\text { the Applicants" (para 52). }\end{array}$ \\
\hline $\begin{array}{l}\text { Top Grade Solutions Inc. v. } \\
\text { Flying Pizza } 73 \text { Inc., } 2009 \\
\text { ABQB } 492\end{array}$ & $\begin{array}{l}\text { Not a Material } \\
\text { Advance }\end{array}$ & $\begin{array}{l}\text { Serving Producible Documents } \\
\text { "Especially since the Defendants were unaware that such } \\
\text { an effort was being made, and the ultimate production } \\
\text { was nothing new to the Defendants and therefore was of } \\
\text { very limited value in moving the action along" (para 40). }\end{array}$ \\
\hline \multicolumn{3}{|c|}{ Retention of Experts/Expert Reports } \\
\hline $\begin{array}{l}\text { Mohacsi v. J. Folk \& Associates } \\
\text { Ltd., } 2006 \text { ABQB } 170\end{array}$ & Material Advance & $\begin{array}{l}\text { Agreement Appointing an Expert } \\
\text { "In my opinion, the last 'thing' which materially } \\
\text { advanced the action was the agreement made to permit } \\
\text { 'a mutually acceptable accountant' to review the books } \\
\text { and records" (para 30). }\end{array}$ \\
\hline $\begin{array}{l}\text { Phillips v. Sowan, } 2007 \text { ABCA } \\
101\end{array}$ & Material Advance & $\begin{array}{l}\text { Economic Report to be Used in the Assessment of } \\
\text { Damages } \\
\text { "The economic report and the medical reports gathered } \\
\text { in } 2004 \text { were gathered to assist the respondent in } \\
\text { finalizing positions on the injuries and economic loss } \\
\text { sustained which would form the subject of a settlement } \\
\text { proposal in the assessment of damages" (para 3). } \\
\text { "Viewed in the context of this particular litigation, and } \\
\text { bearing in mind the high standard of review, the action } \\
\text { taken could be said to have materially advanced this } \\
\text { action" (para 6). }\end{array}$ \\
\hline \multicolumn{3}{|c|}{ Standstill Agreement } \\
\hline $\begin{array}{l}\text { Webber v. Canada (Attorney } \\
\text { General), } 2005 \text { ABQB } 718\end{array}$ & No Material Advance & $\begin{array}{l}\text { "[T]here was no express standstill agreement in place } \\
\text { between the parties during that gap" (para 57). }\end{array}$ \\
\hline
\end{tabular}




\begin{tabular}{|c|c|c|}
\hline Citation & Decision & Reasons for Judgment \\
\hline \multicolumn{3}{|c|}{ Standstill Agreement (continued) } \\
\hline $\begin{array}{l}\text { Craig v. Blue Cross Life } \\
\text { Insurance Company of Canada } \\
\text { (Ontario Blue Cross), } 2010 \\
\text { ABQB } 659\end{array}$ & Material Advance & $\begin{array}{l}\text { "[A]n express standstill agreement was contained in the } \\
\text { July } 15,2004 \text { correspondence" (para 23). }\end{array}$ \\
\hline $\begin{array}{l}\text { Canadian Egg Marketing } \\
\text { Agency v. Villetard, } 2005 \text { ABCA } \\
294\end{array}$ & Material Advance & $\begin{array}{l}\text { "Neither the Master nor the Queen's Bench judge in } \\
\text { chambers inferred a standstill agreement. On the } \\
\text { contrary, both found the existence of a standstill } \\
\text { agreement arising from the express words set out in the } \\
\text { exchange of correspondence between the parties" (para } \\
\text { 6). }\end{array}$ \\
\hline $\begin{array}{l}\text { Bugg v. Beau Canada } \\
\text { Exploration Ltd, } 2006 \text { ABCA } \\
201\end{array}$ & Material Advance & $\begin{array}{l}\text { "Here, the clear implication is that the standstill was to } \\
\text { remain in effect until a statement of defence was filed } \\
\text { (which would constitute a 'thing' and would end the } \\
\text { need for a standstill agreement), or either party gave } \\
\text { reasonable notice that the agreement was to end. As none } \\
\text { of these events occurred, the standstill agreement was } \\
\text { still in effect at the time of the application to dismiss } \\
\text { under R. } 244.1 \text { and the five-year period had not yet } \\
\text { expired" (para 20). }\end{array}$ \\
\hline $\begin{array}{l}\text { Haekel v. Canada, } 2008 \text { ABQB } \\
701\end{array}$ & $\begin{array}{l}\text { Not a Material } \\
\text { Advance }\end{array}$ & $\begin{array}{l}\text { "I find on the facts of the present case that the Master } \\
\text { was correct in his determination that a standstill } \\
\text { agreement was not in effect between the parties. As in } \\
\text { Caillou, the correspondence between counsel is more } \\
\text { properly characterized as a courtesy request from one } \\
\text { lawyer to another, which could be terminated on notice" } \\
\text { (para 30). }\end{array}$ \\
\hline $\begin{array}{l}\text { Black v. Gossner, } 2010 \text { ABQB } \\
360\end{array}$ & Material Advance & $\begin{array}{l}\text { "While the exchange regarding the Statement of Defence } \\
\text { occurred between adjusters, its legal import is that the } \\
\text { Defendants would have had grounds to object if the } \\
\text { Plaintiffs had noted them in default in the circumstances. } \\
\text { In my view, where a defendant has requested an } \\
\text { extension which has been granted by a plaintiff, it is not } \\
\text { then open to the defendant to take advantage of any time } \\
\text { limits which may expire during the currency of the } \\
\text { extension" (para 51). }\end{array}$ \\
\hline \multicolumn{3}{|c|}{ Pre-Trial Conferences/Judicial Dispute Resolutions } \\
\hline $\begin{array}{l}\text { Barnes v. RBC Dominion } \\
\text { Securities Inc., } 2006 \text { ABQB } 290\end{array}$ & $\begin{array}{l}\text { Not a Material } \\
\text { Advance }\end{array}$ & $\begin{array}{l}\text { Request for a Pre-Trial Conference } \\
\text { "The Plaintiff's request for a Pre-Trial Conference did } \\
\text { not materially advance the action" (para 35). }\end{array}$ \\
\hline $\begin{array}{l}\text { Courtoreille v. Edmonton (City), } \\
2008 \text { ABCA } 90\end{array}$ & Material Advance & $\begin{array}{l}\text { Pre-Trial Conference } \\
\text { "The Chambers judge concluded that this direction } \\
\text { materially advanced the action. His conclusion was } \\
\text { supported by the evidence. He committed no palpable } \\
\text { and overriding error in reaching that conclusion" (para } \\
\text { 12). }\end{array}$ \\
\hline
\end{tabular}




\begin{tabular}{|c|c|c|}
\hline Citation & Decision & Reasons for Judgment \\
\hline \multicolumn{3}{|c|}{ Pre-Trial Conferences/Judicial Dispute Resolutions (continued) } \\
\hline $\begin{array}{l}\text { Kurian v. Alberta (Motor } \\
\text { Vehicle Accident Claims Act, } \\
\text { Administrator), } 2007 \text { ABQB } 369\end{array}$ & $\begin{array}{l}\text { Not a Material } \\
\text { Advance }\end{array}$ & $\begin{array}{l}\text { Preparation for a JDR } \\
\text { "I conclude the pursuance of and preparation for the } \\
\text { J.D.R. was not a thing that materially advanced the } \\
\text { actions" (para 72). }\end{array}$ \\
\hline \multicolumn{3}{|c|}{ Applications } \\
\hline $\begin{array}{l}\text { Malhomme v. Merlin, } 2006 \\
\text { ABCA } 361\end{array}$ & Material Advance & $\begin{array}{l}\text { Procedural Order } \\
\text { "In summary, I am satisfied that Merlin's application } \\
\text { for, inter alia, advice and direction and a trial on the } \\
\text { issues is not a substantive action to which r. } 244.1 \text { can } \\
\text { apply" (para 24). }\end{array}$ \\
\hline $\begin{array}{l}155569 \text { Canada Limited v. } \\
57618 \text { Manitoba Ltd., } 2006 \\
\text { ABQB } 919\end{array}$ & Material Advance & $\begin{array}{l}\text { Application re Summary Judgment } \\
\text { "As a result, it is my view that the hearing of the motion } \\
\text { can be considered a 'thing' for purposes of the 'drop } \\
\text { dead rule"' (para 13). }\end{array}$ \\
\hline $\begin{array}{l}\text { Day Rider v. Shouting, } 2006 \\
\text { ABQB } 461\end{array}$ & $\begin{array}{l}\text { Not a Material } \\
\text { Advance }\end{array}$ & $\begin{array}{l}\text { Application re Expert Reports (not served) } \\
\text { "Inquiries by the Plaintiff in relation to medical } \\
\text { information were only communicated to the other side in } \\
\text { a tangential manner, late in the day and with no real } \\
\text { benefit to the progress of the action" (para 23). }\end{array}$ \\
\hline $\begin{array}{l}\text { Bilawchuk v. Lorie Management } \\
\text { \& Holdings Ltd., } 2007 \text { ABQB } \\
395\end{array}$ & Material Advance & $\begin{array}{l}\text { Application \& Order to Dispense with Examinations for } \\
\text { Discovery } \\
\text { "Accordingly, I have concluded that the motion } \\
\text { constituted a thing which materially advanced the action } \\
\text { for purposes of the Rule" (para 4). }\end{array}$ \\
\hline $\begin{array}{l}\text { Nelson v. Emsland, } 2008 \text { ABCA } \\
387\end{array}$ & $\begin{array}{l}\text { Not a Material } \\
\text { Advance }\end{array}$ & $\begin{array}{l}\text { Application for Security for Costs (that did not proceed) } \\
\text { "A court process that does not materially advance a } \\
\text { claim is not a 'thing' within the meaning of Rule } \\
244.1(1) \text {. The application for security for costs, even if it } \\
\text { had proceeded, would not have materially advanced the } \\
\text { counterclaim" (para 13). }\end{array}$ \\
\hline $\begin{array}{l}\text { Vincent v. Moduline Industries } \\
\text { (Canada) Ltd., } 2011 \text { ABQB } 571\end{array}$ & Dismissal & $\begin{array}{l}\text { Noting in Default and Order Setting Aside Noting in } \\
\text { Default } \\
\text { "In the circumstances I find that neither the noting in } \\
\text { default, nor the subsequent order setting it aside, } \\
\text { significantly advanced the action" (para 67). }\end{array}$ \\
\hline \multicolumn{3}{|c|}{ Notices } \\
\hline $\begin{array}{l}\text { Underwood v. Sturgeon County, } \\
2005 \text { ABQB } 713\end{array}$ & Material Advance & $\begin{array}{l}\text { Service of Notice to Admit without Reply } \\
\text { "The Defendant's failure to respond to the request for } \\
\text { documents may demonstrate the Defendant's } \\
\text { acquiescence or participation in the delay. Further, the } \\
\text { Defendant is not allowed to rely on [its] own delay in } \\
\text { bringing a Rule } 244.1 \text { type of action" (para } 30 \text { ). }\end{array}$ \\
\hline $\begin{array}{l}\text { Matco Investments Ltd. v. Dhow } \\
\text { Properties Ltd., } 2010 \text { ABQB } \\
104\end{array}$ & $\begin{array}{l}\text { Not a Material } \\
\text { Advance }\end{array}$ & $\begin{array}{l}\text { Service of Notice to Admit without Reply } \\
\text { "In conclusion, I find that none of the admissions sought } \\
\text { in the Notice to Admit Facts are in contention in this } \\
\text { litigation. Therefore, the Notice to Admit Facts does not } \\
\text { materially advance the action" (para 41). }\end{array}$ \\
\hline
\end{tabular}




\begin{tabular}{|c|c|c|}
\hline Citation & Decision & Reasons for Judgment \\
\hline \multicolumn{3}{|c|}{ Notices (continued) } \\
\hline $\begin{array}{l}\text { Kapicki v. Kapicki, } 2010 \text { ABQB } \\
615\end{array}$ & Material Advance & $\begin{array}{l}\text { Service of Notice to Disclose/Consent Order } \\
\text { "However, by agreeing, through the Consent Order, to } \\
\text { produce information related to exemptions claimed in } \\
\text { relation to an action for the division of matrimonial } \\
\text { property, the Plaintiff participated in a process which } \\
\text { would materially advance the matrimonial property } \\
\text { action" (para 20). }\end{array}$ \\
\hline $\begin{array}{l}\text { Barnes v. RBC Dominion } \\
\text { Securities Inc., } 2006 \text { ABQB } 290\end{array}$ & $\begin{array}{l}\text { Not a Material } \\
\text { Advance }\end{array}$ & $\begin{array}{l}\text { Service of Notice of Change of Solicitors } \\
\text { "The Change of Solicitors filed herein did not advance } \\
\text { the action. Filing and serving a Notice of Change of } \\
\text { Solicitors does not advance the action and merely serves } \\
\text { to notify all other parties of the change that has already } \\
\text { occurred" (para 34). }\end{array}$ \\
\hline $\begin{array}{l}\text { Calliou v. Bouchard, } 2006 \\
\text { ABQB } 925\end{array}$ & $\begin{array}{l}\text { Not a Material } \\
\text { Advance }\end{array}$ & $\begin{array}{l}\text { Service of Notice of Change of Solicitors } \\
\text { "Surely a change of legal representation for the Plaintiffs } \\
\text { has no effect whatsoever on the progress of litigation" } \\
\text { (para 15). }\end{array}$ \\
\hline $\begin{array}{l}\text { Reimer v. Simms, } 2006 \text { ABQB } \\
326\end{array}$ & $\begin{array}{l}\text { Not a Material } \\
\text { Advance }\end{array}$ & $\begin{array}{l}\text { Service of a Notice of Change of Solicitors } \\
\text { "Filing and serving a notice of change of solicitors is } \\
\text { also not a "thing"" (para 31). }\end{array}$ \\
\hline $\begin{array}{l}\text { Kurian v. Alberta (Motor } \\
\text { Vehicle Accident Claims Act, } \\
\text { Administrator), } 2007 \text { ABQB } 369\end{array}$ & Material Advance & $\begin{array}{l}\text { Notice of Motion } \\
\text { "[T] he Notice of Motion to vary the contempt order and } \\
\text { remove the stays constitutes a thing that materially } \\
\text { advances the actions" (para } 77 \text { ). }\end{array}$ \\
\hline $\begin{array}{l}\text { BEW v. Alberta, (Child, Youth } \\
\text { and Family Enhancement Act, } \\
\text { Director), } 2010 \text { ABQB } 796\end{array}$ & $\begin{array}{l}\text { Not a Material } \\
\text { Advance }\end{array}$ & Notice of Motion to Strike a Statement of Defence \\
\hline \multicolumn{3}{|c|}{ Affidavits } \\
\hline $\begin{array}{l}\text { Haekel v. Canada, } 2008 \text { ABQB } \\
701\end{array}$ & $\begin{array}{l}\text { Not a Material } \\
\text { Advance }\end{array}$ & $\begin{array}{l}\text { Filing an Affidavit of Service } \\
\text { "Although filing the affidavit of service is a step that } \\
\text { must be taken before noting a defendant in default, it is } \\
\text { not a step that is required before proceeding to trial. In } \\
\text { my view, it is not a thing that materially advanced the } \\
\text { action as against the Applicants" (para 50). }\end{array}$ \\
\hline \multicolumn{3}{|c|}{ Parallel or Linked Actions } \\
\hline $\begin{array}{l}\text { Robson v. Cosco, } 2006 \mathrm{ABCA} \\
373\end{array}$ & $\begin{array}{l}\text { Not a Material } \\
\text { Advance }\end{array}$ & $\begin{array}{l}\text { "Assuming that a step was taken within the five years on } \\
\text { the Woolco action, that does not assist the Appellant on } \\
\text { the Tirecraft action which was severed" (para 3). }\end{array}$ \\
\hline $\begin{array}{l}\text { Angevine v. Blue Range } \\
\text { Resource Corporation, } 2007 \\
\text { ABQB } 443\end{array}$ & $\begin{array}{l}\text { Not a Material } \\
\text { Advance }\end{array}$ & $\begin{array}{l}\text { "First, I agree with the Master that nothing determined in } \\
\text { the Commission hearing would be relevant and binding } \\
\text { to the case at bar because such determinations are made } \\
\text { pursuant to the public interest jurisdiction of the } \\
\text { Commission and although the proceedings may be } \\
\text { related they are not inextricably linked" (para 46). }\end{array}$ \\
\hline
\end{tabular}




\begin{tabular}{|c|c|c|}
\hline Citation & Decision & Reasons for Judgment \\
\hline \multicolumn{3}{|c|}{ Parallel or Linked Actions (continued) } \\
\hline $\begin{array}{l}\text { Lord v. Bell-Lord, } 2007 \text { ABQB } \\
274\end{array}$ & $\begin{array}{l}\text { Not a Material } \\
\text { Advance }\end{array}$ & \\
\hline \multicolumn{3}{|c|}{ Steps After 244.1(1) Application Filed } \\
\hline D.S. v. Alberta, 2005 ABQB 677 & $\begin{array}{l}\text { Not a Material } \\
\text { Advance }\end{array}$ & $\begin{array}{l}\text { "While they admit there was delay, the Plaintiffs say, in } \\
\text { response, that the delay has now been cured by the } \\
\text { service of their Replies to both the Demands for } \\
\text { Particulars" (para 11). }\end{array}$ \\
\hline \multicolumn{3}{|c|}{ Certificate of Readiness } \\
\hline $\begin{array}{l}\text { Lanset Capital Corp. v. } \\
\text { Waterloo Geological Consulting } \\
\text { Ltd., } 2006 \text { ABCA } 77\end{array}$ & $\begin{array}{l}\text { Not a Material } \\
\text { Advance }\end{array}$ & $\begin{array}{l}\text { "The August/September } 2004 \text { agreement of counsel that } \\
\text { the matter could be set down for trial once the } \\
\text { undertakings had been performed, did not materially } \\
\text { advance the action" (para 9). }\end{array}$ \\
\hline $\begin{array}{l}\text { Day Rider v. Shouting, } 2006 \\
\text { ABQB } 461\end{array}$ & $\begin{array}{l}\text { Not a Material } \\
\text { Advance }\end{array}$ & $\begin{array}{l}\text { "A motion to set the matter down for trial drifted } \\
\text { aimlessly" (para 23). }\end{array}$ \\
\hline
\end{tabular}


TABLE 8: SUMmary ANALYSIS

of Cases under Transitional RULe 15.4

\begin{tabular}{|c|c|c|}
\hline Citation & Decision & Reasons for Judgment \\
\hline \multicolumn{3}{|c|}{ Settlement Offers/Meetings } \\
\hline $\begin{array}{l}\text { Montreal Trust Company of } \\
\text { Canada v. Talcorp Limited, } \\
2013 \text { ABQB } 398\end{array}$ & Significant Advance & $\begin{array}{l}\text { "This agreement narrowed the issues and the scope and } \\
\text { duration of the litigation. It was an agreement reached at } \\
\text { a 'without prejudice' meeting to negotiate possible } \\
\text { settlement. It was an agreement which is a thing done to } \\
\text { significantly advance the action" (para 61). }\end{array}$ \\
\hline \multicolumn{3}{|c|}{ Questionings \& Answers to Undertakings } \\
\hline $\begin{array}{l}\text { Le v. } 1055168 \text { Alberta Ltd., } 2013 \\
\text { ABQB } 431\end{array}$ & Significant Advance & $\begin{array}{l}\text { Answers to Undertakings } \\
\text { "I do not suggest that a defendant must harass a plaintiff } \\
\text { for undertaking responses, but if the defendant intends to } \\
\text { use Rule } 4.33 \text { or Rule } 15.4 \text { and argue that compliance } \\
\text { with undertakings did not move the lawsuit along, it is } \\
\text { surely incumbent on the defendant to take some steps to } \\
\text { secure compliance rather than sit back and hope the } \\
\text { plaintiff falls asleep" (para 36). }\end{array}$ \\
\hline Brar v. Pawa, 2010 ABQB 779 & Significant Advance & $\begin{array}{l}\text { Answers to Undertakings } \\
\text { "In this case over } 100 \text { undertakings were responded to, } \\
\text { involving in Ms. Pawa's case some three binders of } \\
\text { documents. Furthermore voluminous correspondence } \\
\text { was exchanged that dealt with more than superficial } \\
\text { matters, and discussions were undertaken about the } \\
\text { retention of an expert. It is clear from a functional } \\
\text { perspective that steps were being taken by the parties } \\
\text { during the alleged five year gap to materially and } \\
\text { significantly move the matter toward trial" (para 33). }\end{array}$ \\
\hline \multicolumn{3}{|c|}{ Retention of Experts/Expert Reports } \\
\hline $\begin{array}{l}\text { Huynh v. Rosman, } 2013 \text { ABQB } \\
218\end{array}$ & $\begin{array}{l}\text { Not a Significant } \\
\text { Advance }\end{array}$ & $\begin{array}{l}\text { Obtaining Information Without Providing to the Other } \\
\text { Party } \\
\text { "In a case where the thing done is the collection of } \\
\text { information, the determination if the litigation was } \\
\text { moved closer to trial will depend on a number of factors, } \\
\text { including the importance of the information, the extent } \\
\text { of the information, the quality of the information, } \\
\text { whether the opposing party was aware the information } \\
\text { was being gathered, and if the information was ever } \\
\text { provided to the opposing party" (para 35). }\end{array}$ \\
\hline \multicolumn{3}{|c|}{ Pre-Trial Conference/Judicial Dispute Resolution } \\
\hline $\begin{array}{l}\text { St. Jean Estate v. Edmonton } \\
\text { (City), } 2014 \text { ABQB } 47\end{array}$ & $\begin{array}{l}\text { Not a Significant } \\
\text { Advance }\end{array}$ & $\begin{array}{l}\text { Pre-Trial Conference } \\
\text { "The clear and simple fact is that nothing meaningful } \\
\text { transpired at or after the meeting to advance the } \\
\text { litigation" (para 30). }\end{array}$ \\
\hline
\end{tabular}




\begin{tabular}{|c|c|c|}
\hline Citation & Decision & Reasons for Judgment \\
\hline \multicolumn{3}{|c|}{ Pre-Trial Conference/Judicial Dispute Resolution (continued) } \\
\hline $\begin{array}{l}\text { Donnelly v. Brick Warehouse } \\
\text { Corporation, } 2013 \text { ABQB } 621\end{array}$ & $\begin{array}{l}\text { Not a Significant } \\
\text { Advance }\end{array}$ & $\begin{array}{l}\text { Pre-Trial Conference } \\
\text { "When one reviews the pre-trial conference report that } \\
\text { Phillips J prepared, it appears that the parties were ready } \\
\text { to proceed with the trial. No further steps had to be } \\
\text { taken, except those that would be done as the trial date } \\
\text { approached, such as the exchange of expert reports, } \\
\text { preparation of an agreed statement of facts, and an } \\
\text { exhibit binder. In other words, the pre-trial conference } \\
\text { did not materially advance the action" (para 25). }\end{array}$ \\
\hline \multicolumn{3}{|c|}{ Applications } \\
\hline $\begin{array}{l}\text { Donnelly v. Brick Warehouse } \\
\text { Corporation, } 2013 \text { ABQB } 621\end{array}$ & $\begin{array}{l}\text { Not a Significant } \\
\text { Advance }\end{array}$ & $\begin{array}{l}\text { Application for a Jury Trial } \\
\text { "Even if his application to have this matter heard before } \\
\text { a civil jury is a 'thing,' which this Court does not accept, } \\
\text { the commencement of that application by the filing of } \\
\text { the notice of motion on November 30, 2012, does not } \\
\text { complete the "thing." As Fruman JA stated in Morasch } \\
\text { at para 7, 'The step must be completed, however, not just } \\
\text { commenced"" (para 32). }\end{array}$ \\
\hline $\begin{array}{l}\text { Wiens v. Dewald, } 2012 \text { ABQB } \\
172\end{array}$ & Significant Advance & $\begin{array}{l}\text { Application for an Order to File a Form } 37 \\
\text { "Therefore, the Master's conclusion that the filing of a } \\
\text { Form } 37 \text { by a specific date outside the drop dead time } \\
\text { would significantly advance the action was eminently } \\
\text { reasonable" (para 24). }\end{array}$ \\
\hline $\begin{array}{l}\text { Carter v. Sears Canada Inc., } \\
2011 \text { ABQB } 732\end{array}$ & $\begin{array}{l}\text { Not a Significant } \\
\text { Advance }\end{array}$ & $\begin{array}{l}\text { Stay for Plaintiff to Provide an Address for Service } \\
\text { "Where, however, the Action has been stayed until the } \\
\text { Plaintiff takes an identified step, such as providing an } \\
\text { address for service, as is the case here, the Plaintiff has } \\
\text { the sole power to take that step and to move the matter } \\
\text { forward. The Plaintiff also has the obligation to do so. } \\
\text { Having failed to take that step, the Plaintiff cannot now } \\
\text { hide behind the Stay" (para 41). }\end{array}$ \\
\hline \multicolumn{3}{|c|}{ Affidavits } \\
\hline $\begin{array}{l}\text { Franchuk v. Schick, } 2013 \text { ABQB } \\
532\end{array}$ & Significant Advance & $\begin{array}{l}\text { Filing a Witness Affidavit } \\
\text { "The Kwasnycia Affidavit advances the action in a way } \\
\text { similar to the provision of information to the opposing } \\
\text { party. The September 4, } 2012 \text { Letter is an } \\
\text { acknowledgement by the Defendant that the filing of the } \\
\text { Kwasnycia Affidavit is a significant advance that moved } \\
\text { the litigation closer to trial" (para 16). }\end{array}$ \\
\hline \multicolumn{3}{|c|}{ Parallel or Linked Actions } \\
\hline $\begin{array}{l}\text { Bahcheli v. Yorkton Securities } \\
\text { Inc., } 2012 \text { ABCA } 166\end{array}$ & $\begin{array}{l}\text { Not a Significant } \\
\text { Advance }\end{array}$ & $\begin{array}{l}\text { Parallel Regulatory Litigation } \\
\text { "In this case, I am convinced that nothing done after the } \\
\text { statement of claim was issued was of any benefit } \\
\text { whatever in the present lawsuit, let alone materially } \\
\text { advancing it" (para 43). }\end{array}$ \\
\hline
\end{tabular}


Table 9: Summary Analysis

of Cases from Rule 4.33 Applications

\begin{tabular}{|c|c|c|}
\hline Citation & Decision & Reasons for Judgment \\
\hline \multicolumn{3}{|c|}{ Pleadings } \\
\hline Brost v. Kusler, 2016 ABCA 363 & Significant Advance & $\begin{array}{l}\text { Statement of Defence to Counterclaim } \\
\text { "Both the context and a functional analysis of this } \\
\text { pleading lead us to conclude that the statement of } \\
\text { defence to counterclaim was a step which significantly } \\
\text { advanced this action" (para 20). } \\
\text { It was not a boiler plate document (para 18). }\end{array}$ \\
\hline $\begin{array}{l}\text { Deja Vu Holdings Ltd. v. } \\
\text { Securex Master Limited } \\
\text { Partnership, } 2018 \text { ABQB } 597\end{array}$ & $\begin{array}{l}\text { Not a Significant } \\
\text { Advance }\end{array}$ & $\begin{array}{l}\text { Statement of Defence to Counterclaim } \\
\text { "[T] }] \text { he Statement of Defence to Counterclaim here is } \\
\text { truly a general, boilerplate denial that does not } \\
\text { significantly advance the Action" (para 32). }\end{array}$ \\
\hline \multicolumn{3}{|c|}{ Affidavit of Records/Supplemental Affidavit of Records } \\
\hline \multirow[t]{2}{*}{$\begin{array}{l}\text { Ro-Dar Contracting Ltd. v. } \\
\text { Verbeek Sand \& Gravel Inc., } \\
2016 \text { ABCA } 123\end{array}$} & $\begin{array}{l}\text { Not a Significant } \\
\text { Advance }\end{array}$ & $\begin{array}{l}\text { If the supplemental affidavit of records was just } \\
\text { "housekeeping," and merely listed documents that were } \\
\text { already known, it does not advance the action (para 9). }\end{array}$ \\
\hline & Significant Advance & $\begin{array}{l}\text { The production of new information can significantly } \\
\text { advance an action, especially if the documents are } \\
\text { important to both sides (para 29). }\end{array}$ \\
\hline $\begin{array}{l}\text { Weaver v. Cherniawsky, } 2016 \\
\text { ABCA } 152\end{array}$ & $\begin{array}{l}\text { Not a Significant } \\
\text { Advance }\end{array}$ & $\begin{array}{l}\text { Further production must narrow the issues or assist the } \\
\text { respondents in assessing the strengths and weaknesses of } \\
\text { the case, or move the matter closer to resolution (para } \\
24) \text {. }\end{array}$ \\
\hline $\begin{array}{l}\text { XS Technologies Inc. v. Veritas } \\
\text { DGC Land Ltd., } 2016 \text { ABCA } \\
165\end{array}$ & $\begin{array}{l}\text { Not a Significant } \\
\text { Advance }\end{array}$ & $\begin{array}{l}\text { "[T]he Supplemental Affidavit, served over six years } \\
\text { after a request and containing documents which existed, } \\
\text { for the most part, prior to the original affidavit of } \\
\text { records, and certainly no later than } 2009 \text {, did not } \\
\text { significantly advance the action" (para 17). }\end{array}$ \\
\hline $\begin{array}{l}\text { Huerto v. Canniff, } 2015 \text { ABCA } \\
316\end{array}$ & $\begin{array}{l}\text { Not a Significant } \\
\text { Advance }\end{array}$ & $\begin{array}{l}\text { Additional documents included in the Supplemental } \\
\text { Affidavit of Records were not relevant and material } \\
\text { because they did not help to determine an issue raised in } \\
\text { the pleadings (para 8). }\end{array}$ \\
\hline Alberta v. Cox, 2017 ABCA 5 & Significant Advance & $\begin{array}{l}\text { "[B]oth Actions were significantly advanced when Cox } \\
\text { handed over the remaining records on February 2, 2009, } \\
\text { given the nature and quality of some records, as they } \\
\text { clarified Cox's position and narrowed the issues in } \\
\text { dispute" (para 30). }\end{array}$ \\
\hline $\begin{array}{l}\text { Ursa Ventures Ltd. v. Edmonton } \\
\text { (City), } 2016 \text { ABCA } 135\end{array}$ & Significant Advance & $\begin{array}{l}\text { "A mutual possession of similar or identical records by } \\
\text { the parties does not destroy the meaning or foundation or } \\
\text { the significance of the records described by either party } \\
\text { in the Affidavit of Records. Disclosure of similar or } \\
\text { identical records by the litigants means each litigant } \\
\text { knows the records produced by the adverse party could } \\
\text { be evidence in the litigation process. Specifically, Ursa's } \\
\text { Affidavit of Records discloses to the City the records in }\end{array}$ \\
\hline
\end{tabular}




\begin{tabular}{|c|c|c|}
\hline Citation & Decision & Reasons for Judgment \\
\hline \multicolumn{3}{|c|}{ Affidavit of Records/Supplemental Affidavit of Records (continued) } \\
\hline $\begin{array}{l}\text { Ursa Ventures Ltd. v. Edmonton } \\
\text { (City), } 2016 \text { ABCA } 135 \\
\text { (continued) }\end{array}$ & Significant Advance & $\begin{array}{l}\text { Ursa's possession and which records Ursa might use to } \\
\text { attempt to prove its case at trial. The fact the records } \\
\text { might be the same or identical to the records of the City } \\
\text { does not impact Ursa's claim nor does it mean Ursa's } \\
\text { Affidavit of Records does not significantly advance the } \\
\text { action. To the contrary it advises the City of the nature, } \\
\text { quality and quantity of Ursa's records. It further allows } \\
\text { the City to know the nature of Ursa's production } \\
\text { evidence which the City possibly will have to meet in } \\
\text { order to defend the claims of Ursa at trial" (para 28). }\end{array}$ \\
\hline $\begin{array}{l}\text { Deja Vu Holdings Ltd. v. } \\
\text { Securex Master Limited } \\
\text { Partnership, } 2018 \text { ABQB } 597\end{array}$ & $\begin{array}{l}\text { Not a Significant } \\
\text { Advance }\end{array}$ & $\begin{array}{l}\text { Because the documents included in the Supplemental } \\
\text { Affidavit of Records were documents already in } \\
\text { existence when the original Affidavit of Records was } \\
\text { filed, the action was dismissed (para 38). }\end{array}$ \\
\hline $\begin{array}{l}\text { Forest Resource Improvement } \\
\text { Association of Alberta v. Moore, } \\
2015 \text { ABQB } 588\end{array}$ & $\begin{array}{l}\text { Not a Significant } \\
\text { Advance }\end{array}$ & $\begin{array}{l}\text { "I cannot find that they were relevant or material. As } \\
\text { such, the disclosure of these documents did not } \\
\text { significantly advance the action or bring the matter } \\
\text { closer to resolution" (para 32). }\end{array}$ \\
\hline $\begin{array}{l}\text { John Barlot Architect Ltd. v. } \\
\text { Atrium Square Investments Ltd., } \\
2017 \text { ABQB } 749\end{array}$ & Significant Advance & $\begin{array}{l}\text { Damages Calculation with Supporting Documentation } \\
\text { "Steps which narrow the issues for trial, define the } \\
\text { positions of the parties or identify the evidence upon } \\
\text { which they will be relying at trial have all been found to } \\
\text { meet the test in Rule } 4.33 \text { " (para 10). } \\
\text { "These documents quantify Barlot's claim in a way that } \\
\text { could precipitate settlement discussions or at least } \\
\text { crystallize issues for trial" (para 21). }\end{array}$ \\
\hline $\begin{array}{l}\text { Altex International Heat } \\
\text { Exchanger Ltd. v. Foster } \\
\text { Wheeler Limited, } 2018 \mathrm{ABQB} \\
620\end{array}$ & $\begin{array}{l}\text { Not a Significant } \\
\text { Advance }\end{array}$ & $\begin{array}{l}\text { "The evidence supports the conclusion that } 60 \text { of the } 108 \\
\text { documents provided in the Supplemental Affidavit of } \\
\text { Records had already been provided as far back as } 2001 \text {. } \\
\text { About } 25 \text { are from before } 2003 \text {, and for those that came } \\
\text { from the Receiver, the Defendant would have had those } \\
\text { documents since 2010, according to an Affidavit sworn } \\
\text { in 2012" (para 116). }\end{array}$ \\
\hline $\begin{array}{l}\text { Terroco Drilling Ltd. v. Tusk } \\
\text { Energy Corporation, } 2014 \\
\text { ABQB } 419\end{array}$ & $\begin{array}{l}\text { Not a Significant } \\
\text { Advance }\end{array}$ & $\begin{array}{l}\text { Provision of Producible Documents } \\
\text { "Undertaking a functional analysis, I have come to the } \\
\text { conclusion that the provision to opposing counsel upon } \\
\text { his or her request of copies of records already made } \\
\text { available for viewing by way of the Affidavit of Records } \\
\text { does not significantly advance the action" (para 34). }\end{array}$ \\
\hline \multicolumn{3}{|c|}{ Settlement Offers/Meetings } \\
\hline $\begin{array}{l}\text { Sutherland v. Brown, } 2018 \\
\text { ABCA } 123\end{array}$ & $\begin{array}{l}\text { Not a Significant } \\
\text { Advance }\end{array}$ & $\begin{array}{l}\text { Settlement Offer } \\
\text { A without-prejudice settlement offer, which admitted } \\
\text { partial liability, did not move the action forward (para } \\
\text { 16). }\end{array}$ \\
\hline
\end{tabular}




\begin{tabular}{|c|c|c|}
\hline Citation & Decision & Reasons for Judgment \\
\hline \multicolumn{3}{|c|}{ Settlement Offers/Meetings (continued) } \\
\hline $\begin{array}{l}\text { Ro-Dar Contracting Ltd. v. } \\
\text { Verbeek Sand \& Gravel Inc., } \\
2016 \text { ABCA } 123\end{array}$ & Significant Advance & $\begin{array}{l}\text { Settlement Discussions } \\
\text { Settlement discussions could significantly advance an } \\
\text { action if they resolve any part of the action or narrow the } \\
\text { issues in any material respects (para 8). }\end{array}$ \\
\hline Nash v. Snow, 2014 ABQB 355 & $\begin{array}{l}\text { Not a Significant } \\
\text { Advance }\end{array}$ & $\begin{array}{l}\text { Settlement Offer } \\
\text { "I agree that a significant advancement towards } \\
\text { resolution can mean advancement to settlement. } \\
\text { However, a functional analysis mandates something } \\
\text { more than a bare offer to settle in the three year window; } \\
\text { it must result in progress of some sort in the action" } \\
\text { (para 47). }\end{array}$ \\
\hline $\begin{array}{l}1406998 \text { Alberta Ltd. } v . \\
\text { Dorbandt, } 2018 \text { ABCA } 213\end{array}$ & Significant Advance & $\begin{array}{l}\text { Settlement Offer } \\
\text { "The settlement offer is strong evidence that the time } \\
\text { committed to the process was valuable" (para 2). }\end{array}$ \\
\hline $\begin{array}{l}\text { Brace v. McKen, } 2019 \text { ABCA } \\
135\end{array}$ & $\begin{array}{l}\text { Not a Significant } \\
\text { Advance }\end{array}$ & $\begin{array}{l}\text { Settlement Offer } \\
\text { "On August 26, } 2015 \mathrm{McKen} \text { offered to settle by } \\
\text { accepting a discontinuance of action without costs. This } \\
\text { certainly did not complete the discovery or provide any } \\
\text { documents, none of which has still occurred. Nor did it } \\
\text { serve to narrow the issues. Applying a functional and } \\
\text { pragmatic approach, these two offers did not } \\
\text { significantly advance the action" (para 21). }\end{array}$ \\
\hline $\begin{array}{l}\text { Roman Catholic Bishop of the } \\
\text { Diocese of Calgary v. Schuster, } \\
2019 \text { ABCA } 64\end{array}$ & Significant Advance & $\begin{array}{l}\text { Partial Discontinuance of Action } \\
\text { "The discontinuances of action in the factual context } \\
\text { here accords with the functional approach to litigation. } \\
\text { The number of defendants was reduced and issues were } \\
\text { narrowed. Unquestionably, the necessary trial time is } \\
\text { also reduced" (para 27). }\end{array}$ \\
\hline $\begin{array}{l}\text { Delver v. Gladue, } 2019 \text { ABCA } \\
54\end{array}$ & $\begin{array}{l}\text { Not a Significant } \\
\text { Advance }\end{array}$ & $\begin{array}{l}\text { Without Prejudice Settlement Offer } \\
\text { "There is no evidence that the plaintiff here provided any } \\
\text { important new information within the relevant three year } \\
\text { period, or that the proposals made by her narrowed the } \\
\text { issues or clarified the parties' positions. While the } \\
\text { outcome of any step is not determinative, the test is } \\
\text { whether there was a significant advance in the action, not } \\
\text { whether unaccepted proposals or attempted procedures } \\
\text { could have resulted in a significant advance in other } \\
\text { circumstances" (para 13). }\end{array}$ \\
\hline \multicolumn{3}{|c|}{ Questionings \& Answers to Undertakings } \\
\hline $\begin{array}{l}\text { Hickaway v. Riddell Kurczaba } \\
\text { Architecture Engineering } \\
\text { Interior Design Ltd., } 2015 \\
\text { ABCA } 69\end{array}$ & Significant Advance & $\begin{array}{l}\text { Answers to Undertakings } \\
\text { "All one can infer from these steps is that both parties } \\
\text { allowed the action to lapse for too long, but the plaintiff } \\
\text { woke up before the three-year period expired and then } \\
\text { showed resolve to conclude the action with some } \\
\text { assistance from the Court" (para 5). }\end{array}$ \\
\hline
\end{tabular}




\begin{tabular}{|c|c|c|}
\hline Citation & Decision & Reasons for Judgment \\
\hline \multicolumn{3}{|c|}{ Questionings \& Answers to Undertakings (continued) } \\
\hline $\begin{array}{l}\text { Janstar Homes Ltd. v. Elbow } \\
\text { Valley West Ltd., } 2016 \text { ABCA } \\
417\end{array}$ & $\begin{array}{l}\text { Not a Significant } \\
\text { Advance }\end{array}$ & $\begin{array}{l}\text { Exchange of Letters Seeking Questioning Dates } \\
\text { "The exchange of correspondence with respect to dates } \\
\text { for questioning in itself did not significantly advance this } \\
\text { action" (para 31). }\end{array}$ \\
\hline Nash v. Snow, 2014 ABQB 355 & $\begin{array}{l}\text { Not a Significant } \\
\text { Advance }\end{array}$ & $\begin{array}{l}\text { Alleged Answers to Undertakings } \\
\text { "Even if the statements in the Letter could be deemed to } \\
\text { be responses to undertakings, they would not qualify as a } \\
\text { significant advancement. They were perfunctory } \\
\text { answers, which do not avoid the application of the long } \\
\text { delay Rule" (para 45). }\end{array}$ \\
\hline $\begin{array}{l}\text { M L Bruce Holdings Inc. v. Ceco } \\
\text { Developments Ltd., } 2015 \text { ABQB } \\
604\end{array}$ & Significant Advance & $\begin{array}{l}\text { Answers to Undertakings } \\
\text { "[T]he answers to undertakings here did significantly } \\
\text { advance the action. The answers were not simply 'I } \\
\text { don't know' or 'I can't find the document', which would } \\
\text { leave the parties in the same position as they were when } \\
\text { the undertaking was given. It is not necessary to review } \\
\text { the information set out in them; some answers here were } \\
\text { meaningful" (para 34). }\end{array}$ \\
\hline $\begin{array}{l}\text { Altex International Heat } \\
\text { Exchanger Ltd. v. Foster } \\
\text { Wheeler Limited, } 2018 \mathrm{ABQB} \\
620\end{array}$ & $\begin{array}{l}\text { Not a Significant } \\
\text { Advance }\end{array}$ & $\begin{array}{l}\text { Answers to Undertakings } \\
\text { "The evidence supports the conclusion that } 60 \text { of the } 108 \\
\text { documents provided in the Supplemental Affidavit of } \\
\text { Records had already been provided as far back as } 2001 \text {. } \\
\text { About } 25 \text { are from before 2003, and for those that came } \\
\text { from the Receiver, the Defendant would have had those } \\
\text { documents since 2010, according to an Affidavit sworn } \\
\text { in 2012" (para 116). }\end{array}$ \\
\hline $\begin{array}{l}221198 \text { Alberta Ltd. v. } \\
\text { Dobrescu, } 2017 \text { ABQB } 460\end{array}$ & Significant Advance & $\begin{array}{l}\text { Answers to Undertakings } \\
\text { "Given this, it can hardly be said that this action had } \\
\text { died. While the information contained in the answers to } \\
\text { undertakings may not have provided much in the way of } \\
\text { new evidence, it did confirm the Respondents' position } \\
\text { in relation to trial issues (for example, by confirming the } \\
\text { loss of profit claim and its calculation). That, together } \\
\text { with the securing of trial dates, did move the parties } \\
\text { closer to resolution" (para 17). }\end{array}$ \\
\hline \multicolumn{3}{|c|}{ Retention of Experts/Expert Reports } \\
\hline $\begin{array}{l}\text { Huerto v. Canniff, } 2015 \text { ABCA } \\
316\end{array}$ & $\begin{array}{l}\text { Not a Significant } \\
\text { Advance }\end{array}$ & $\begin{array}{l}\text { Retention of Experts } \\
\text { Although the applicant did retain experts, the retention } \\
\text { was not communicated to the respondents, nor was the } \\
\text { information gathered by the experts shared (para 10). }\end{array}$ \\
\hline \multicolumn{3}{|c|}{ Standstill Agreement } \\
\hline $\begin{array}{l}\text { Flock v. Flock Estate, } 2017 \\
\text { ABCA } 67\end{array}$ & $\begin{array}{l}\text { Not a Significant } \\
\text { Advance }\end{array}$ & $\begin{array}{l}\text { Implied Standstill Agreement } \\
\text { "Silence is not acquiescence, and acquiescence does not } \\
\text { amount to an 'express' standstill agreement. Plaintiffs } \\
\text { cannot be 'lulled' into inactivity by vagueness about the } \\
\text { reach of this mandatory rule" (para 22). The standstill } \\
\text { must be express (para 17). }\end{array}$ \\
\hline
\end{tabular}




\begin{tabular}{|c|c|c|}
\hline Citation & Decision & Reasons for Judgment \\
\hline \multicolumn{3}{|c|}{ Standstill Agreement (continued) } \\
\hline $\begin{array}{l}\text { Brian W Conway Professional } \\
\text { Corporation v. Perera, } 2015 \\
\text { ABCA } 404\end{array}$ & $\begin{array}{l}\text { Not a Significant } \\
\text { Advance }\end{array}$ & $\begin{array}{l}\text { Alleged Email Standstill Agreement } \\
\text { "We observe that while the words 'standstill agreement' } \\
\text { are not required for an agreement to constitute a } \\
\text { standstill agreement in law, it is prudent practice for } \\
\text { counsel, in circumstances where a standstill agreement } \\
\text { under rule 4.33.(1)(a) is intended, that the words } \\
\text { 'standstill agreement' and reference to the rule be } \\
\text { specified" (para 32). }\end{array}$ \\
\hline $\begin{array}{l}\text { Turek v. Oliver, } 2014 \text { ABCA } \\
327\end{array}$ & Significant Advance & $\begin{array}{l}\text { Agreement Between Counsel Regarding Deadlines } \\
\text { "The drop dead rule was never designed to encourage } \\
\text { the sort of ambush that was unleashed here, after months } \\
\text { of courtesies by one side and obfuscation and } \\
\text { unresponsiveness by the other" (para 6). }\end{array}$ \\
\hline $\begin{array}{l}330626 \text { Alberta Ltd. v. Ho \& } \\
\text { Laviolette Engineering Ltd., } \\
2018 \text { ABQB } 398\end{array}$ & Significant Advance & $\begin{array}{l}\text { Standstill Agreement } \\
\text { "I find that by exchange of correspondence on August } \\
12,2016 \text {, those moving defendants and } 330626 \text { entered } \\
\text { into a suspension or 'standstill agreement' pursuant to r } \\
4.33(5) \text { such that their applications fail on this ground" } \\
\text { (para 108). }\end{array}$ \\
\hline \multicolumn{3}{|c|}{ Pre-Trial Conferences/Judicial Dispute Resolutions } \\
\hline $\begin{array}{l}\text { Weaver v. Cherniawsky, } 2016 \\
\text { ABCA } 152\end{array}$ & $\begin{array}{l}\text { Not a Significant } \\
\text { Advance }\end{array}$ & $\begin{array}{l}\text { Agreement to Participate (only) in an ADR/JDR } \\
\text { A mandatory step in the Rules such as attending some } \\
\text { form of ADR before a trial date can be requested "is not } \\
\text { always or necessarily a significant advance in an action" } \\
\text { (para 22). }\end{array}$ \\
\hline $\begin{array}{l}1406998 \text { Alberta Ltd. } v . \\
\text { Dorbandt, } 2018 \text { ABCA } 213\end{array}$ & Significant Advance & $\begin{array}{l}\text { Judicial Dispute Resolution } \\
\text { "The parties filed briefs on the JDR, and devoted } \\
\text { sufficient time to ensure the JDR process was effective" } \\
\text { (para 2). }\end{array}$ \\
\hline $\begin{array}{l}\text { Milne v. Dziadyk, } 2014 \text { ABQB } \\
407\end{array}$ & $\begin{array}{l}\text { Not a Significant } \\
\text { Advance }\end{array}$ & $\begin{array}{l}\text { Attempts to Schedule a JDR } \\
\text { "That case is in step with a line of cases that holds that } \\
\text { planning a step in an action or discussing the taking of a } \\
\text { step in an action, such as the setting of the action down } \\
\text { for trial, does not significantly advance the action" (para } \\
\text { 9). }\end{array}$ \\
\hline $\begin{array}{l}\text { Fletcher Challenge Energy } \\
\text { Canada Inc. v. Jonust Farms } \\
\text { Ltd., } 2014 \text { ABQB } 518\end{array}$ & $\begin{array}{l}\text { Not a Significant } \\
\text { Advance }\end{array}$ & Attempts to Schedule a JDR \\
\hline $\begin{array}{l}\text { Vander Griendt v. Canvest } \\
\text { Capital Management Corp., } \\
2014 \text { ABQB } 542\end{array}$ & Significant Advance & $\begin{array}{l}\text { Case Management Meetings } \\
\text { "In my view, it is clear that there have been significant } \\
\text { advances in this action since June } 5,2011 \text {. For example, } \\
\text { I was appointed case management justice and the matter } \\
\text { has been in active case management with regular case } \\
\text { management meetings. Several affidavits have been filed } \\
\text { and some of the affiants have been cross-examined. One } \\
\text { of those cross-examinations gave rise to a hotly-disputed }\end{array}$ \\
\hline
\end{tabular}




\begin{tabular}{|c|c|c|}
\hline Citation & Decision & Reasons for Judgment \\
\hline \multicolumn{3}{|c|}{ Pre-Trial Conferences/Judicial Dispute Resolutions (continued) } \\
\hline $\begin{array}{l}\text { Vander Griendt v. Canvest } \\
\text { Capital Management Corp., } \\
2014 \text { ABQB } 542 \text { (continued) }\end{array}$ & Significant Advance & $\begin{array}{l}\text { application to compel answers to several contested } \\
\text { undertakings, resolution of which required me to issue a } \\
\text { written decision. These are among the steps that have } \\
\text { genuinely advanced the action during the period of } \\
\text { alleged delay" (para 103). }\end{array}$ \\
\hline $\begin{array}{l}\text { Thiessen v. Corbiell, } 2019 \\
\text { ABCA } 56\end{array}$ & $\begin{array}{l}\text { Not a Significant } \\
\text { Advance }\end{array}$ & $\begin{array}{l}\text { Efforts to Consolidate Actions and Attend Mediation } \\
\text { "[W]e find that the trial judge's conclusion that the } \\
\text { parties' 'efforts to consolidate the actions for trial' } \\
\text { significantly advanced the actions reflects palpable and } \\
\text { overriding error" (para 26). }\end{array}$ \\
\hline \multicolumn{3}{|c|}{ Applications } \\
\hline $\begin{array}{l}\text { Steparyk v. Alberta, } 2015 \text { ABCA } \\
125\end{array}$ & $\begin{array}{l}\text { Not a Significant } \\
\text { Advance }\end{array}$ & $\begin{array}{l}\text { Application for Advance Costs } \\
\text { "[T] he appellant's application for advance funding of the } \\
\text { litigation by itself did not significantly advance the } \\
\text { action" (para 14). }\end{array}$ \\
\hline Alberta v. Cox, 2017 ABCA 5 & Significant Advance & $\begin{array}{l}\text { Application for Summary Judgment } \\
\text { "Because of the evidence adduced to support and } \\
\text { respond to a summary judgment application, it may be a } \\
\text { significant advance that narrows and defines the issues } \\
\text { for trial and advances the case toward resolution in a } \\
\text { meaningful way" (para 25). }\end{array}$ \\
\hline \multicolumn{3}{|c|}{ Consent Orders } \\
\hline $\begin{array}{l}\text { Canada (Attorney General) v. } \\
\text { Delorme, } 2016 \text { ABCA } 168\end{array}$ & $\begin{array}{l}\text { Not a Significant } \\
\text { Advance }\end{array}$ & $\begin{array}{l}\text { Even through the order resolved a dispute, it did not } \\
\text { resolve another dispute over the same issue, and it was } \\
\text { not a formal step leading to resolution (para 39). }\end{array}$ \\
\hline \multicolumn{3}{|c|}{ Notices } \\
\hline Nash v. Snow, 2014 ABQB 355 & $\begin{array}{l}\text { Not a Significant } \\
\text { Advance }\end{array}$ & $\begin{array}{l}\text { Notice to Admit Facts } \\
\text { "To significantly advance an action, an admission sought } \\
\text { from the other party must be relevant. This means not } \\
\text { only relevant to the issues in the litigation, but relevant } \\
\text { in the sense that it adds something new" (para 55). }\end{array}$ \\
\hline $\begin{array}{l}\text { XS Technologies Inc. v. Veritas } \\
\text { DGC Land Ltd., } 2016 \text { ABCA } \\
165\end{array}$ & $\begin{array}{l}\text { Not a Significant } \\
\text { Advance }\end{array}$ & $\begin{array}{l}\text { Notice of Written Questioning } \\
\text { "In our view, the Notice bears greater similarity to a } \\
\text { notice to admit facts. It is not the notice to admit that } \\
\text { significantly advances the action; it is the admission, an } \\
\text { unreasonable refusal to admit or a lapse of time with no } \\
\text { reply" (para 26). }\end{array}$ \\
\hline $\begin{array}{l}\text { Krieter v. Alberta, } 2014 \text { ABQB } \\
349\end{array}$ & $\begin{array}{l}\text { Not a Significant } \\
\text { Advance }\end{array}$ & $\begin{array}{l}\text { Notice to Admit Facts \& Reply } \\
\text { "A response to a Notice to Admit that refuses to admit } \\
\text { the facts does not significantly advance an action" (para } \\
27 \text { ). } \\
\text { "Where the Reply admits some facts, those admissions } \\
\text { must be examined to determine if they materially } \\
\text { advance the action. If none of the admitted facts were in } \\
\text { contention by the parties, the test will not be met" (para } \\
28 \text { ). }\end{array}$ \\
\hline
\end{tabular}




\begin{tabular}{|c|c|c|}
\hline Citation & Decision & Reasons for Judgment \\
\hline \multicolumn{3}{|c|}{ Notices (continued) } \\
\hline $\begin{array}{l}\text { Forest Resource Improvement } \\
\text { Association of Alberta v. Moore, } \\
2015 \text { ABQB } 588\end{array}$ & $\begin{array}{l}\text { Not a Significant } \\
\text { Advance }\end{array}$ & $\begin{array}{l}\text { Notice to Attend Questioning } \\
\text { "[I]t would depend on an examination of the } \\
\text { circumstances including whether there was a real need } \\
\text { for the questioning" (para 24). }\end{array}$ \\
\hline $\begin{array}{l}\text { Phillips v. Whyew, } 2014 \text { ABQB } \\
495\end{array}$ & $\begin{array}{l}\text { Not a Significant } \\
\text { Advance }\end{array}$ & $\begin{array}{l}\text { Notice to Attend Questioning } \\
\text { "These cases all support the conclusion that service of a } \\
\text { notice of appointment for an examination for discovery } \\
\text { or questioning does not significantly advance the action" } \\
\text { (para 15). }\end{array}$ \\
\hline \multicolumn{3}{|c|}{ Affidavits } \\
\hline $\begin{array}{l}\text { Vander Griendt v. Canvest } \\
\text { Capital Management Corp., } \\
2014 \text { ABQB } 542\end{array}$ & Significant Advance & $\begin{array}{l}\text { Affidavits Filed and Cross-Examined On } \\
\text { "In my view, it is clear that there have been significant } \\
\text { advances in this action since June 5, 2011. For example, } \\
\text { I was appointed case management justice and the matter } \\
\text { has been in active case management with regular case } \\
\text { management meetings. Several affidavits have been filed } \\
\text { and some of the affiants have been cross-examined. One } \\
\text { of those cross-examinations gave rise to a hotly-disputed } \\
\text { application to compel answers to several contested } \\
\text { undertakings, resolution of which required me to issue a } \\
\text { written decision. These are among the steps that have } \\
\text { genuinely advanced the action during the period of } \\
\text { alleged delay" (para 103). }\end{array}$ \\
\hline $\begin{array}{l}\text { Morrison v. Galvanic Applied } \\
\text { Sciences Inc., } 2017 \text { ABQB } 514\end{array}$ & $\begin{array}{l}\text { Not a Significant } \\
\text { Advance }\end{array}$ & $\begin{array}{l}\text { Supporting Affidavit to Originating Application } \\
\text { "Mr. Morrison's affidavit does not assert any new } \\
\text { information" (para 23). }\end{array}$ \\
\hline \multicolumn{3}{|c|}{ Participation After Drop-Dead Deadline } \\
\hline $\begin{array}{l}\text { Fletcher Challenge Energy } \\
\text { Canada Inc. v. Jonust Farms } \\
\text { Ltd., } 2014 \text { ABQB } 518\end{array}$ & $\begin{array}{l}\text { Not a Significant } \\
\text { Advance }\end{array}$ & $\begin{array}{l}\text { "In short, drop dead applications will fail where } \\
\text { defendants have actively participated in an action to an } \\
\text { extent and degree that could lead a plaintiff to fairly } \\
\text { assume that the defendant has waived the delay" (para } \\
58 \text { ). } \\
\text { The Master did not find that was the circumstance in this } \\
\text { case. }\end{array}$ \\
\hline \multicolumn{3}{|c|}{ Attempts to Set Matter Down for Trial } \\
\hline $\begin{array}{l}\text { Pomedli v. Allied Machinists } \\
\text { Limited, } 2015 \text { ABQB } 146\end{array}$ & $\begin{array}{l}\text { Not a Significant } \\
\text { Advance }\end{array}$ & Attempts to set matter for trial were unsuccessful. \\
\hline \multicolumn{3}{|c|}{ Parallel or Linked Actions } \\
\hline $\begin{array}{l}\text { Bahcheli v. Yorkton Securities } \\
\text { Inc., } 2012 \text { ABCA } 166\end{array}$ & $\begin{array}{l}\text { Not a Significant } \\
\text { Advance }\end{array}$ & $\begin{array}{l}\text { Parallel Regulatory Litigation } \\
\text { "In this case, I am convinced that nothing done after the } \\
\text { statement of claim was issued was of any benefit } \\
\text { whatever in the present lawsuit, let alone materially } \\
\text { advancing it" (para 43). }\end{array}$ \\
\hline $\begin{array}{l}\text { Danek v. Levine, } 2016 \text { ABQB } \\
422\end{array}$ & $\begin{array}{l}\text { Not a Significant } \\
\text { Advance }\end{array}$ & $\begin{array}{l}\text { Reliance on Steps in an Inextricably Linked Action } \\
\text { No inextricable link found. }\end{array}$ \\
\hline
\end{tabular}




\begin{tabular}{|c|c|c|}
\hline Citation & Decision & Reasons for Judgment \\
\hline \multicolumn{3}{|c|}{ Parallel or Linked Actions (continued) } \\
\hline $\begin{array}{l}\text { Pappas v. BCE Inc., } 2014 \\
\text { ABQB } 49\end{array}$ & $\begin{array}{l}\text { Not a Significant } \\
\text { Advance }\end{array}$ & $\begin{array}{l}\text { Reliance on Steps in an Inextricably Linked Action from } \\
\text { Another Province } \\
\text { No inextricable link between jurisdictions. }\end{array}$ \\
\hline \multicolumn{3}{|c|}{ Delay Because of Psychological Issues } \\
\hline $\begin{array}{l}\text { Wilson v. Board of Trustees of } \\
\text { Aspen View Regional School } \\
\text { Division No. 19, } 2014 \text { ABQB } \\
741\end{array}$ & $\begin{array}{l}\text { Not a Significant } \\
\text { Advance }\end{array}$ & $\begin{array}{l}\text { "Rules like } 4.33 \text { are absolute and mandatory. Rule } 4.33 \\
\text { was intended by the drafters to be a 'bright line rule', } \\
\text { subject to the exceptions in rule } 4.33(1)(\mathrm{a})-(\mathrm{d}) \text {; which } \\
\text { reminds us that the privilege to litigate in this venue is } \\
\text { fairly easily lost. Bright line rules are intended to be } \\
\text { largely impervious to the entreaties of equity, or the } \\
\text { blurring of their boundaries" (para } 20 \text { ). }\end{array}$ \\
\hline $\begin{array}{l}\text { Chorney v. Thompson, } 2014 \\
\text { ABQB } 410\end{array}$ & $\begin{array}{l}\text { Not a Significant } \\
\text { Advance }\end{array}$ & Alleged Incapacity \\
\hline
\end{tabular}

